
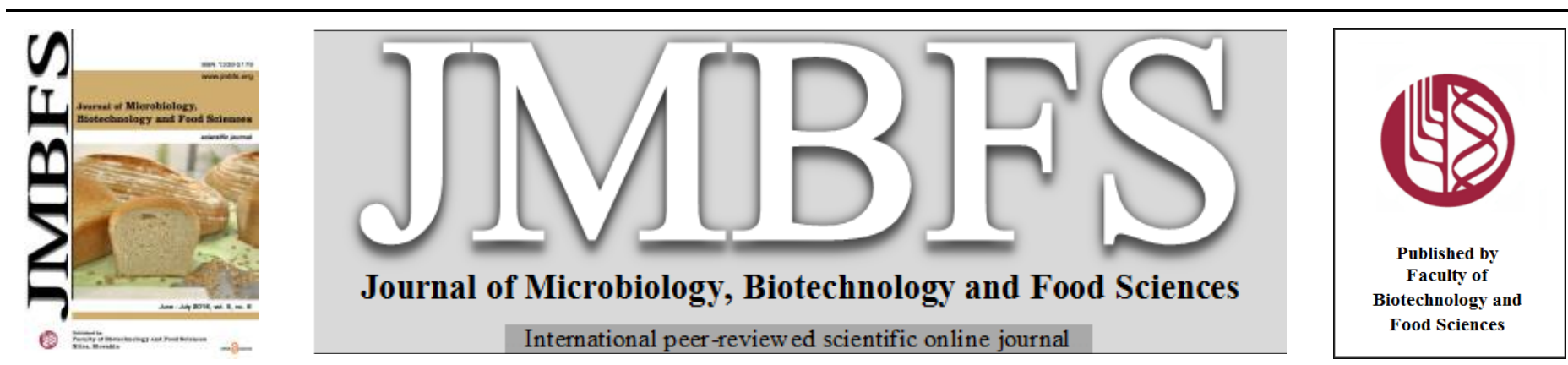

\title{
BOX-BEHNKEN EXPERIMENTAL DESIGN MEDIATED OPTIMIZATION OF AQUEOUS METHYLPARATHION BIODEGRADATION BY Pseudomonas aeruginosa mpd STRAIN
}

\author{
Krishnaswamy Usharani $*^{1,2,3}$, Perumalsamy Lakshmanaperumalsamy ${ }^{2}$ \\ $\operatorname{Address}(e s)$ : \\ ${ }^{1}$ Division of Environmental Microbiology. \\ ${ }^{2}$ Division of Environmental Engineering and Technology, Department of Environmental Sciences, Bharathiar University, TN, India. \\ ${ }^{3}$ Department of Environmental Science, Central University of Kerala, KL, India.
}

*Corresponding author: usharanik05@yahoo.com

doi: 10.15414/jmbfs.2016.5.6.534-547

ARTICLE INFO

Received 22. 2. 2015

Revised 14. 11. 2015

Accepted 24. 1. 2016

Published 1. 6. 2016

Regular article

open $\partial_{\text {ACCESS }}$

\begin{abstract}
Biotreatment of methylparathion was studied in aqueous mineral salts medium containing bacterial culture to demonstrate the potential of the novel strain of Pseudomonas aeruginosa mpd. A statistical Box-Behnken Design (BBD) of experiments was performed to evaluate the effects of individual operating variables and their interactions on the methylparathion removal with initial concentration of $1000 \mathrm{mg} \mathrm{l}^{-1}$ as fixed input parameter. The temperature $\left(\mathrm{X}_{1}\right), \mathrm{pH}\left(\mathrm{X}_{2}\right)$, reaction time $\left(\mathrm{X}_{3}\right)$ and agitation $\left(\mathrm{X}_{4}\right)$ were used as design factors. The result was shown that experimental data fitted with the polynomial model. Analysis of variance showed a high coefficient of determination value 0.9 . The optimum biodegradation of MP in terms MP removal $\left(\mathrm{Y}_{1}\right)$, COD removal $\left(\mathrm{Y}_{2}\right)$ and TOC removal $\left(\mathrm{Y}_{3}\right)$ were found to be $95.2 \%, 82 \%$ and $61.2 \%$ respectively. The maximum growth $\left(\mathrm{Y}_{4}\right)$ was 2.18 optical density (OD). The optimum biodegradation correspond to the factors combination of middle level of $\mathrm{X}_{1}\left(33{ }^{\circ} \mathrm{C}\right), \mathrm{X}_{2}(7.0), \mathrm{X}_{4}(150 \mathrm{rpm})$ and the highest level of $\mathrm{X}_{3}$ (96h). MP removal and its residues were detected using spectral analysis. The study demonstrates the optimum MP biodegradation potential of this strain could use MP as the sole Carbon/Phosphate source. BBD confirmed to be dependable in developing the model, optimizing factors and analyzing interaction effects. Data from this study will be helpful in the design of small-scale field experiments and subsequently an in situ methylparathion biotreatment system for field application.
\end{abstract}

Keywords: Wastewater Biotreatment. Design Optimization. Pseudomonas aeruginosa. Biodegradation. O,O-dimethyl -O-4nitrophenylphosphorothioate

\section{INTRODUCTION}

Continuous and excessive use of organophosphorus (OP) compounds has led to the contamination of several ecosystems in different parts of the world (Cisar and Snyder, 2000; Tse $\boldsymbol{e}$ t al., 2004). Thiophosphoric acid esters, such as parathion, methylparathion (MP) and tetrachlorvinphos, are hazardous pollutants and their accumulation in the environment is a recognized ecological threat (Kaloyanova and Tarkowski, 1981). Methods for their enhanced degradation are an urgent task of contemporary chemical technology and biotechnology. Its widespread use has caused environmental concern due to its frequent leakage into surface and ground waters. The drinking water directive (Council directive 98/ 83/ EC) sets an allowed contaminant level of $0.1 \mathrm{mg} / \mathrm{L}$ for a single pesticide and $0.5 \mathrm{mg} / \mathrm{L}$ for the total sum of pesticides. Industries manufacturing pesticides release wastewater in water bodies or land. Although industries treat their wastewater by activated sludge process, no attention is paid to remove the specific pesticides or their metabolites which exert toxicity at very low concentrations. Therefore, there is a need for economically dependable methods for organophosphorus (OPs) detoxification from the environment. To date, bacterial transformations have been the main focus in research on organophosphate pesticide degradation. Pseudomonas aeruginosa, Clavibacter michiganense (Subhas and Dileep, 2003), Arthrobacter atrocyaneus, Bacillus megaterium and Pseudomonas mendocina (Bhadbhade et al., 2002), Agrobacterium radiobacter (Horne et al., 2002), and other Pseudomonas species (Ramanathan and Lalithakumari, 1999) have been reported to degrade $\mathrm{OP}$ in solutions and soils. Use of specific microorganism adapted to the pesticides, in treatment of industrial effluents is not in practice (Kanekar $\boldsymbol{e t}$ al., 2004). Therefore, research should be concentrated to develop economical but effective microbial processes for the treatment of industrial effluents containing pesticides and take them to field. The aim of this research was to optimize the process variables for the biodegradation potential of the Pseudomonas aeruginosa mpd novel strain using response surface methodology (RSM).

\section{MATERIAL AND METHODS}

\section{Bacterial culture conditions}

A potential bacterial strain (Pseudomonas aeruginosa mpd) was isolated from pesticide exposed agricultural soil. The initial enrichment cultures were established in a synthetic wastewater containing mineral salts medium amended with the methylparathion (Devithion ${ }^{\mathrm{TM}} 50 \%$ EC) as the sole source of carbon and energy. The concentration of methylparathion used was $0.1 \%, \mathrm{pH}$ was adjusted using $1 \mathrm{~N} \mathrm{NaOH}$ and $1 \mathrm{~N} \mathrm{HCl}$ (ELICO - L1127, India). The methylparathion contaminated synthetic wastewater was neutral $\mathrm{pH}$ and the mean value of methylparathion (MP) content was $1000 \mathrm{mg} / \mathrm{L}$, chemical oxygen demand (COD) was $41950 \mathrm{mg} / \mathrm{L}$ and total organic carbon (TOC) was $10459 \mathrm{mg} / \mathrm{L}$. The synthetic wastewater containing higher concentration of methylparathion with maximum level of $1000 \mathrm{mg} / \mathrm{L}$ was used in the present study. Stock solution of pure methylparathion $(98.5 \%$ ) was prepared by dissolving $1 \mathrm{~g}$ in $100 \mathrm{~mL}$ methanol, made up to $1000 \mathrm{~mL}$ of distilled water and was used as a reference for instrumental analysis. It was reported that the pesticide pollution due to wastewater released from formulating or manufacturing pesticide industry were up to $1000 \mathrm{mgL}^{-1}$ (Chiron et al., 1997). Therefore in this research, synthetic wastewater containing methylparathion with maximum concentration of 1000 $\mathrm{mgL}^{-1}$ was used.

Organisms were subsequently grown on nutrient agar medium plates to obtain single colonies. A pure culture of methylparathion-degrading Pseudomonas aeruginosa was isolated by series of replating on MSM with methylparathion agar plates. Minimum inhibitory concentration (MIC) test with plate screening method was carried out to screen methylparathion resistant bacteria using methylparathion MSM with methylparathion agar plates. Based on the MIC test, the five potential bacterial cultures isolated were identified based on their morphological characters and biochemical tests as given in Bergey's Manual of Determinative Bacteriology (Holt et al., 2000). For degradation studies, Pseudomonas aeruginosa was inoculated into sterile shake-bottles containing 250 
$\mathrm{mL}$ of MSM, $0.1 \%$ (w/v) methylparathion and incubated under aerobic conditions on a shaker $(150 \mathrm{rpm})$ for $96 \mathrm{~h}$. The other parameters, i.e., $\mathrm{pH}$ value, culture temperature, time and agitation, were part of the experimental design. All experiments were performed in triplicate, and the results are expressed as an average of three replicates.

\section{Optimization of methylparathion degrading condition by Pseudomonas aeruginosa mpd}

In order to study the effect of variables on the degradation of methylparathion by biotreatment using potential bacterial strain, the process variables include $\mathrm{pH}$, temperature time and agitation were optimized. Experimental design was set using the variables such as $\mathrm{pH}$, temperature, time and agitation. The synthetic wastewater which consists of mineral salts medium amended with the methylparathion was set at various temperature $\left(25-40^{\circ} \mathrm{C}\right), \mathrm{pH}(5-9)$, time $(24-$ $168 \mathrm{~h})$ and agitation (120-180 rpm) for analysis. The concentration of methylparathion used was $1000 \mathrm{mgL}^{-1}$. The $\mathrm{pH}$ was adjusted using $1 \mathrm{~N} \mathrm{NaOH}$ and $1 \mathrm{~N} \mathrm{HCl}$ with the help of $\mathrm{pH}$ meter (ELICO - L1127, India). During this process, estimation of various parameters such as residual methylparathion, COD removal, TOC removal and $\mathrm{pH}$ were analysed to measure the degradability of methylparathion. Response surface methodology (RSM) based on the BoxBehnken design of experiment was used to optimize these parameters and their interaction which significantly influenced methylparathion biodegradation.

\section{Box-Behnken Experimental Design (BBD) of methylparathion bioremova using RSM}

A standard RSM design called Box-Behnken's Design (BBD) for biotreatment process was adopted to study the influence of variables for the removal of aqueous methylparathion. The method can reduce the number of experimental trials needed to evaluate multiple parameters and their interactions and for finding the most suitable condition and prediction of response (Box and Behnken, 1960; Myers and Montgomery, 2002). Among all the RSM designs, BBD requires fewer runs than the others, e.g., 29 runs for a 4 -factor experimenta design. By careful design and analysis of experiments, Box-Behnken design allows calculations of the response function at intermediate levels which were not experimentally studied and shows the direction if one wishes to change the inpu levels to determine the effects on the response (Hamed and Sakr, 2001, Martínez-Toledo and Rodríguez-Vázquez, 2011).

Table 1 The levels of variables in Box-Behnken statistical experiment design

\begin{tabular}{lcccc} 
& & \multicolumn{3}{c}{ Coded level } \\
\cline { 3 - 5 } Variable & Name & $\mathbf{- 1}$ & $\mathbf{0}$ & $\mathbf{+ 1}$ \\
\hline $\mathrm{X}_{1}: \mathrm{A}$ & Temperature $\left({ }^{\circ} \mathrm{C}\right)$ & 25 & 32.5 & 40 \\
$\mathrm{X}_{2}: \mathrm{B}$ & $\mathrm{pH}$ & 5 & 7 & 9 \\
$\mathrm{X}_{3}: \mathrm{C}$ & Time $(\mathrm{h})$ & 24 & 96 & 168 \\
$\mathrm{X}_{4}: \mathrm{D}$ & Agitation $(\mathrm{rpm})$ & 120 & 150 & 180 \\
\hline
\end{tabular}

The relation between the code values and none code values were: $\mathrm{X}_{1}=(\mathrm{A}-32.5) / 7.5, \mathrm{X}_{2}=(\mathrm{B}-7) / 2, \mathrm{X}_{3}=(\mathrm{C}-96) / 72, \mathrm{X}_{4}=(\mathrm{D}-150) / 30$

Table 2 Experimental design with coded and actual values

\begin{tabular}{|c|c|c|c|c|c|c|c|c|}
\hline \multirow[t]{2}{*}{ Run } & $\begin{array}{c}\text { Temp } \\
\left({ }^{\circ} \mathrm{C}\right)\end{array}$ & pH & $\begin{array}{c}\text { Time } \\
\text { (h) }\end{array}$ & $\begin{array}{c}\text { Agitation } \\
\text { (rpm) }\end{array}$ & $\begin{array}{c}\text { Temp } \\
\left({ }^{\circ} \mathrm{C}\right)\end{array}$ & pH & $\begin{array}{c}\text { Time } \\
\text { (h) }\end{array}$ & $\begin{array}{c}\text { Agitation } \\
\text { (rpm) }\end{array}$ \\
\hline & \multicolumn{4}{|c|}{ Coded Values } & \multicolumn{4}{|c|}{ Actual Values } \\
\hline 1 & 1 & 0 & 0 & -1 & 40 & 7 & 96 & 120 \\
\hline 2 & 0 & 1 & 1 & 0 & 32.5 & 9 & 168 & 150 \\
\hline 3 & 0 & 0 & -1 & -1 & 32.5 & 7 & 24 & 120 \\
\hline 4 & -1 & 0 & 0 & -1 & 25 & 7 & 96 & 120 \\
\hline 5 & 1 & 0 & 1 & 0 & 40 & 7 & 168 & 150 \\
\hline 6 & 1 & 1 & 0 & 0 & 40 & 9 & 96 & 150 \\
\hline 7 & -1 & 0 & 1 & 0 & 25 & 7 & 168 & 150 \\
\hline 8 & 0 & 0 & 1 & 1 & 32.5 & 7 & 168 & 180 \\
\hline 9 & -1 & 0 & -1 & 0 & 25 & 7 & 24 & 150 \\
\hline 10 & 1 & 0 & -1 & 0 & 40 & 7 & 24 & 150 \\
\hline 11 & 0 & -1 & 0 & -1 & 32.5 & 5 & 96 & 120 \\
\hline 12 & 0 & 0 & 1 & -1 & 32.5 & 7 & 168 & 120 \\
\hline 13 & 0 & 0 & 0 & 0 & 32.5 & 7 & 96 & 150 \\
\hline 14 & -1 & 0 & 0 & 1 & 25 & 7 & 96 & 180 \\
\hline 15 & 0 & 1 & -1 & 0 & 32.5 & 9 & 24 & 150 \\
\hline 16 & 0 & 0 & 0 & 0 & 32.5 & 7 & 96 & 150 \\
\hline 17 & 0 & 1 & 0 & 1 & 32.5 & 9 & 96 & 180 \\
\hline 18 & 0 & -1 & -1 & 0 & 32.5 & 5 & 24 & 150 \\
\hline 19 & 0 & 1 & 0 & -1 & 32.5 & 9 & 96 & 120 \\
\hline 20 & 0 & -1 & 1 & 0 & 32.5 & 5 & 168 & 150 \\
\hline 21 & 1 & 0 & 0 & 1 & 40 & 7 & 96 & 180 \\
\hline 22 & 0 & -1 & 0 & 1 & 32.5 & 5 & 96 & 180 \\
\hline 23 & 0 & 0 & 0 & 0 & 32.5 & 7 & 96 & 150 \\
\hline 24 & 0 & 0 & 0 & 0 & 32.5 & 7 & 96 & 150 \\
\hline 25 & -1 & 1 & 0 & 0 & 25 & 9 & 96 & 150 \\
\hline 26 & -1 & -1 & 0 & 0 & 25 & 5 & 96 & 150 \\
\hline 27 & 0 & 0 & 0 & 0 & 32.5 & 7 & 96 & 150 \\
\hline 28 & 1 & -1 & 0 & 0 & 40 & 5 & 96 & 150 \\
\hline 29 & 0 & 0 & -1 & 1 & 32.5 & 7 & 24 & 180 \\
\hline
\end{tabular}

Response surface methodology (RSM) based on the BBD of experiment was used to optimize the variables and their interaction which significantly influenced methylparathion biodegradation by the individual strains of Pseudomonas aeruginosa mpd. A four-factor, three-level Box-Behnken design was used in the biotreatment process. The Box-Behnken design is an independent, rotatable quadratic design with no embedded factorial or fractional factorial points where the variable combinations are at the mid-points of the edges of the variable space and at the center. Among all statistical experiment designs, Box-Behnken design requires fewer runs than the others, e.g., 29 runs for a 4 -factor experimental design. The low, middle and high levels of each variable were designated as -1 , 0 , and +1 respectively, as given in Table 1 . For this biotreatment process, the variables and their values in brackets were three levels include temperature (25 $\left.40^{\circ} \mathrm{C}\right), \mathrm{pH}(5-9)$, time $(24-168 \mathrm{~h})$ and agitation $(120-180 \mathrm{rpm})$, at constant methylparathion concentration $1000 \mathrm{mgL}^{-1}(0.1 \%)$. This also enabled the identification of significant effects of interactions for the batch studies. This also enabled the identification of significant effects of interactions for the batch studies. In system involving four significant independent variables $X_{1}, X_{2}, X_{3}$, and $\mathrm{X}_{4}$, the mathematical relationship of the response of these variables can be 
approximated by quadratic (second degree) polynomial equation (Box and Behnken, 1960). A total of 29 experiments were carried out. The design consists of three replicated center points, and a set of six points lying at the midpoints of each edge of the multidimensional cube (Table 2). Response functions, describing variations of dependent factors $(Y)$ (methylparathion removal, COD removal, TOC removal, bacterial growth for bacterial with the independent variables $\left(\mathrm{X}_{\mathrm{i}}\right)$ (temperature, $\mathrm{pH}$, time and agitation) can be written as follows (Eq.1):

$$
\begin{gathered}
Y=b_{0}+\sum_{\text {Linear }} b_{i} x_{i}+\sum_{\substack{b_{i j} x_{i} x_{j} \\
\text { Interaction }}}^{\sum_{(1)}} b_{i i} x_{i i}^{2} \text { Square }
\end{gathered}
$$

Where, $\mathrm{Y}$ is the predicted response in percentage of methylparathion removal, COD removal, TOC removal and bacterial growth in terms of optical density, $b_{0}$ is the offset term and $b_{i}$ is the linear effect while $b_{i i}$ and $b_{i j}$ are the square and the interaction effects, respectively. Experimental data points used in Box-Behnken statistical experiment design are presented in Table 1. The response function coefficients were determined by regression using the experimental data and the Stat-Ease Design Expert 8.0.4 program.

The response functions for percentage of methylparathion removal, COD removal, TOC removal and bacterial growth in terms of optical density were approximated by the standard quadratic polynomial equation as presented in Eq.

\section{$\mathbf{Y}=\mathbf{b}_{0}+\mathbf{b}_{1} \mathbf{X}_{1}+\mathbf{b}_{2} \mathbf{X}_{2}+\mathbf{b}_{3} \mathbf{X}_{3}+\mathbf{b}_{4} \mathbf{X}_{4}+\mathbf{b}_{11} \mathbf{X}_{1}^{2}+\mathbf{b}_{22} \mathbf{X}_{2}^{2}+\mathbf{b}_{33} \mathbf{X}_{3}^{2}+\mathbf{b}_{44} \mathbf{X}_{4}^{2}$ $+b_{12} X_{1} X_{2}+b_{13} X_{1} X_{3}+b_{14} X_{1} X_{4}+b_{23} X_{2} X_{3}+b_{24} X_{2} X_{4}+b_{34} X_{3} X_{4}$ (2)}

Where $Y$ is the predicted response, i.e. the methylparathion removal; $\mathrm{X}_{1}, \mathrm{X}_{2}, \mathrm{X}_{3}$ and $\mathrm{X}_{4}$ are the coded levels of the independent factors: temperature, $\mathrm{pH}$, time and agitation. The regression coefficients are: $b_{0}-$ the intercept term; $b_{1}, b_{2}, b_{3}$ and $b_{4}$ - the linear coefficients; $b_{12}, b_{13}, b_{14}, b_{23} b_{24} b_{34}$ - the interaction coefficients and $b_{11}, b_{22}, b_{33}, b_{44}-$ the quadratic coefficients. The model evaluates the effect of each independent factor on the response.

The normal practice is to test within the feasible range, so that the variation in the process does not mask the factor effect. A total of 29 trials were necessary to estimate the coefficients of the model using multiple linear regressions. Hence, about 29 treatments were conducted in the present study and analysis the variance. The data obtained from 29 experiments, were used to find out the optimum point of the process parameters using Box-Behnken Design in Response surface methodology. All the data were treated with the aid of Design Expert by Stat Ease Inc, Minneapolis (Design Expert. 8.0.4). For this bacterial biotreatmen process, the methylparathion removal conditions are presented in Table 2, according to the experimental design (Table 1).

\section{Preparation of Sample for Residual Analysis}

The biotreated samples were centrifuged at $10,000 \mathrm{rpm}$ for $15 \mathrm{~min}$ using highspeed refrigerator centrifuge (CR22GII- Hitachi, Japan). The centrifuged samples were filtered through $0.2 \mu \mathrm{m}$ sterile syringe nylon filters and then used for analysis of residual methylparathion and intermediate products using HPLC.

\section{Methylparathion determination}

The methylparathion removal efficiency of the bacterial biotreatment process was analyzed in terms of COD, TOC and residual methylparathion concentration of the wastewater before and after the treatment process. The samples were withdrawn at different time intervals after biotreatment from 0 to $168 \mathrm{~h}$ were analyzed for COD, TOC as per standard procedure laid down in APHA (1998) All experiments were performed in triplicates. The $\mathrm{pH}$ of the treated wastewater was adjusted and monitored using $\mathrm{pH}$ meter (ELICO - L1127, India). The residual methylparathion was analysed using UV-Vis spectrophotometer (Shimadzu - UV- 3600, Japan), HPLC (Shimadzu, SPD-20A, Japan) and GC-MS (Perkin Elmer-Clarus 600, Germany).

\section{Estimation of Growth}

Growth in terms of optical density (Bacteria) was estimated. The increase in growth of bacteria for every $24 \mathrm{~h}$ was monitored by measuring optical density (OD) at $600 \mathrm{~nm}$ on a UV-Visible Spectrophotometer (Shimadzu - UV- 3600, Japan).

\section{Spectral Analysis}

Degradation of methyl parathion and subsequent formation and eventual disappearance of intermediate products in the reaction mixture as a function of $\mathrm{pH}$ and time was monitored using UV-Vis spectroscopy. The filtered samples were scanned using UV-Vis-NIR Spectrophotometer (Shimadzu - UV- 3600 ,
Japan), at $277 \mathrm{~nm}$. The centrifuged and filtered samples were analyzed for residual methylparathion using HPLC, (Shimadzu, Japan) on a reverse phase C18 column $[(250 \times 4.60 \mathrm{~mm})$ (Desc. Luna $5 \mu \mathrm{C} 18$ (20)-100A Phenomenex)], at flow rate of $1.5 \mathrm{~mL} \mathrm{~min}{ }^{-1}$. Mobile phases consisted of solution A (HPLC grade water) and solution B (HPLC grade methanol) in the ratio of 1:4 respectively. The isocratic gradient mode with pressure limit of $20 \mathrm{MPa}$ and the total run time for $20 \mathrm{~min}$. The sample was injected at a rate of $20 \mu \mathrm{L}$ and was detected at 277nm using UV detector (SPD-20A, Japan). Under the conditions described above, the retention time (RT) of methylparathion standard was $3.3 \mathrm{~min}$.

\section{RESULTS AND DISCUSSION}

Box-Behnken Experimental design and statistical analysis of methylparathion biotreatment

Box-behnken statistical experimental design was used to investigate the effects of the three independent variables on the response function and to determine the optimal conditions for maximizing the removal of methylparathion, COD, TOC and growth of bacteria. The optimization procedure involves studying the response of the statistically designed combinations, estimating the coefficients by fitting the experimental data to the response functions, predicting the response of the fitted model and checking the adequacy of the model. The independent variables were the temperature $\left(\mathrm{X}_{1}\right), \mathrm{pH}\left(\mathrm{X}_{2}\right)$, time $\left(\mathrm{X}_{3}\right)$ and agitation $\left(\mathrm{X}_{4}\right)$. The low, center (middle) and high levels of each variable are designated as $-1,0$, and +1 , respectively as shown in Table 1 . The response functions are the methylparathion removal $\left(\mathrm{Y}_{1}\right)$, COD removal $\left(\mathrm{Y}_{2}\right)$, TOC removal $\left(\mathrm{Y}_{3}\right)$ and growth of bacteria $\left(\mathrm{Y}_{4}\right)$. The experimental values and predicted values are presented in Table 2 . The center point $(0,0,0,0,0)$ was repeated five times and the same results were obtained indicating the reproducibility of the data Observed and predicted removal $(\%)$ for methylparathion, COD, TOC and bacterial growth (OD) are compared in Table 3. Yuan et al., (2006) reported optimization of a medium for enhancing nicotine biodegradation by Ochrobactrum intermedium DN2 by using RSM. Furthermore Usharani $\boldsymbol{e}$ t al., (2013) reported optimization of Phosphate removal by bacterial consortium in batch scale process using response surface methodology. Results obtained during the present study showed the importance of using RSM based on the BBD of experiment for the optimization of aqueous methylparathion biotreatment and degradation by potential microbial strains.

\section{Analysis of Variance}

The data obtained from the experiments were used for the analysis of variance Table 4 and 5, shows the ANOVA results of the model of response surface showing the removal of methylparathion, COD and TOC by Pseudomonas aeruginosa mpd and its growth in terms of optical density as a function of temperature, $\mathrm{pH}$, time and agitation. The model F-value obtained (6903.04, $3961.11,4683.83$ and 4.55) from each source implied the respective model was significant for the removal of methylparathion, COD, TOC and bacterial growth in terms of optical density. The ' $\mathrm{P}$ ' value lower than $0.01 \%$ (or 0.0001 ) indicates that the respective model is considered to be statistically significant (Montgomery 1991, 2004). In Table 5, the "lack of fit F- value" of 1.45 for methylparathion removal, 0.36 for COD removal, 2.90 for TOC removal and 1.5 for growth in OD implies that the lack of fit phenomenon is not important relatively to pure error, indicating the suggested model is well fitted to the observed methylparathion removal, COD removal, TOC removal and growth of Pseudomonas sp in OD. Figure 1, show their actual and predicted plot for (a) methylparathion removal, (b) COD removal, (c) TOC removal and (d) growth The actual values are the measured response data for particular run and the predicted values are the results generated using the approximating functions. It was found that the removal of methylparathion, COD, TOC and bacterial growth (OD) which measured the signal to noise ratio was greater than 4 , reaching the ratio of $135.92,69.66,43.75$ and 30.60 , respectively indicates an adequate signal. This indicates the model is adequate to be used to navigate the design space.

\section{The Regression Model Coefficients}

The application of RSM offers an empirical relationship between the response function and the independent variables. The mathematical relationship between the response function (Y) and the independent variables $(\mathrm{X})$ can be approximated by a quadratic polynomial equation as given in Eq. 2. By applying multiple regression analysis of the experimental data, the experimental results were fitted with a second-order polynomial equation. Thus, mathematical regression models for methylparathion removal using the coded factors are given in Eqs. (1) - (4).

$Y_{1}=95.2+4.67 X_{1}+2.75 X_{2}+5.75 X_{3}-2.67 X_{4}-20.81 X_{1}{ }^{2}-18.18 X_{2}{ }^{2}-19.18 X_{3}{ }^{2}$

$14.31 X_{4}{ }^{2}-0.50 X_{1} X_{2}+4.25 X_{1} X_{3}-7.75 X_{1} X_{4}-4.50 X_{2} X_{3}+2.25 X_{2} X_{4}-3.0 X_{3} X_{4}$ 
$Y_{2}=82.0-0.757 X_{1}+2.5 X_{2}+1.33 X_{3}+2.58 X_{4}-13.25 X_{1}{ }^{2}-11.87 X_{2}{ }^{2}-15.62 X_{3}{ }^{2}-$

$17.50 X_{4}^{2}-1.50 X_{1} X_{2}+1.0 X_{1} X_{3}-4.25 X_{1} X_{4}+1.0 X_{2} X_{3}+1.0 X_{2} X_{4}+2.50 X_{3} X_{4}$

(2)
$Y_{4}=2.18-0.075 X_{1}+0.13 X_{2}+0.13 X_{3}+0.12 X_{4}-0.38 X_{1}{ }^{2}-0.44 X_{2}{ }^{2}-0.38 X_{3}^{2}-$ $0.56 X_{4}{ }^{2}-0.025 X_{1} X_{2}-0.025 X_{1} X_{3}-0.17 X_{1} X_{4}+0.25 X_{2} X_{3}+0.13 X_{2} X_{4}+0.15 X_{3} X_{4}$

$Y_{3}=61.2-1.257 X_{1}+2.58 X_{2}+0.92 X_{3}+1.75 X_{4}-15.98 X_{1}^{2}-12.73 X_{2}^{2}-$ $15.47 X_{3}^{2}-19.22 X_{4}^{2}-0.25 X_{1} X_{2}+2.25 X_{1} X_{3}-4.75 X_{1} X_{4}+4.25 X_{2} X_{3}+2.25 X_{2} X_{4}$

Where $\mathrm{Y}_{1}$ (\% methylparathion removal), $\mathrm{Y}_{2}$ (\% COD removal), $\mathrm{Y}_{3}$ (\% TOC removal) and $\mathrm{Y}_{4}$ (bacterial growth in $\left.\mathrm{OD}\right)$ is the predicted responses where as the $\mathrm{X}_{1}$ (temperature), $\mathrm{X}_{2}$ (initial $\mathrm{pH}$ ), $\mathrm{X}_{3}$ (time) and $\mathrm{X}_{4}$ (agitation) are the coded variables.

Table 3 The observed (experimental) values and model response (predicted) values obtained from combination of process variables

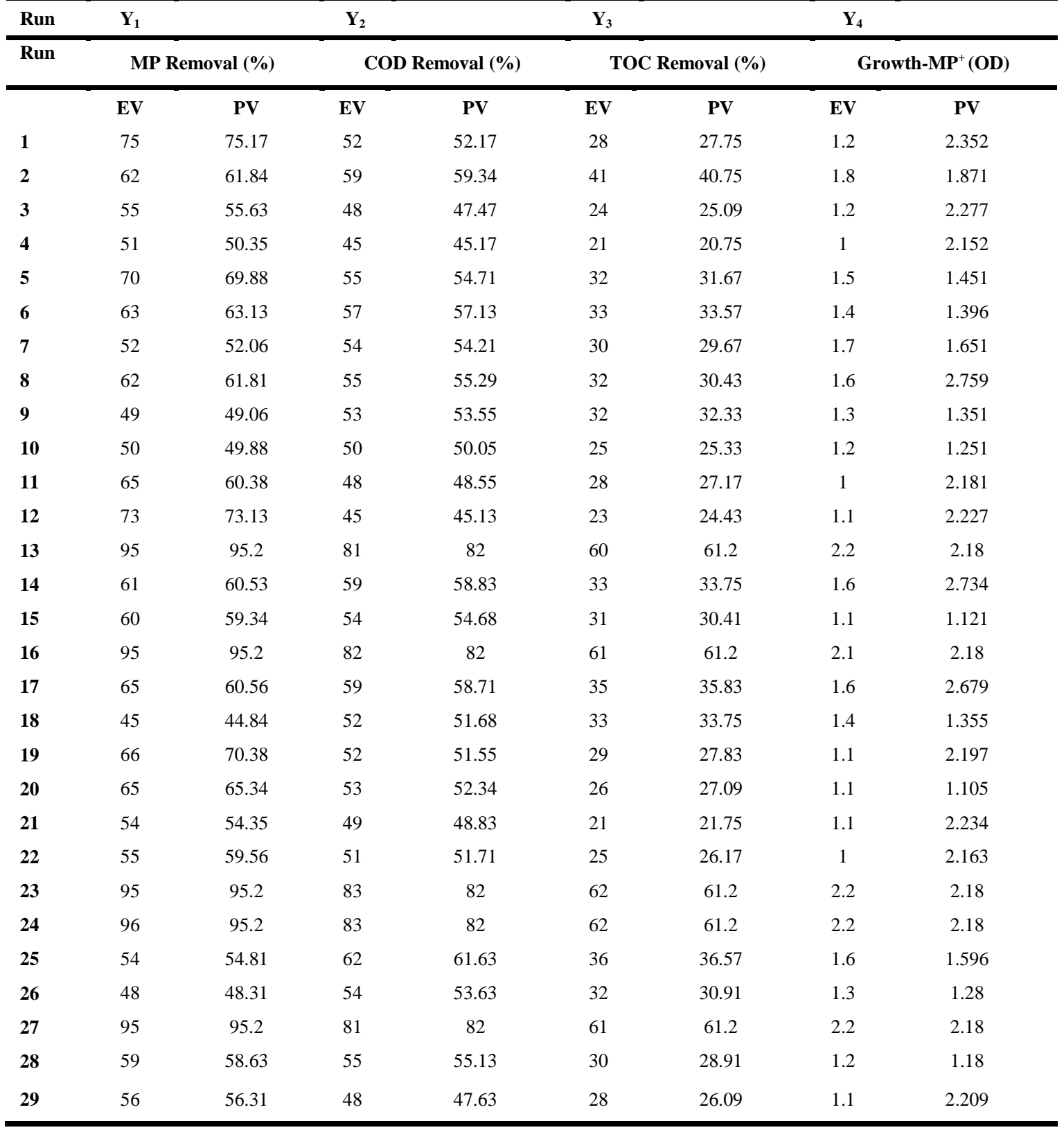

Experimental values - EV; Predicted values - PV 


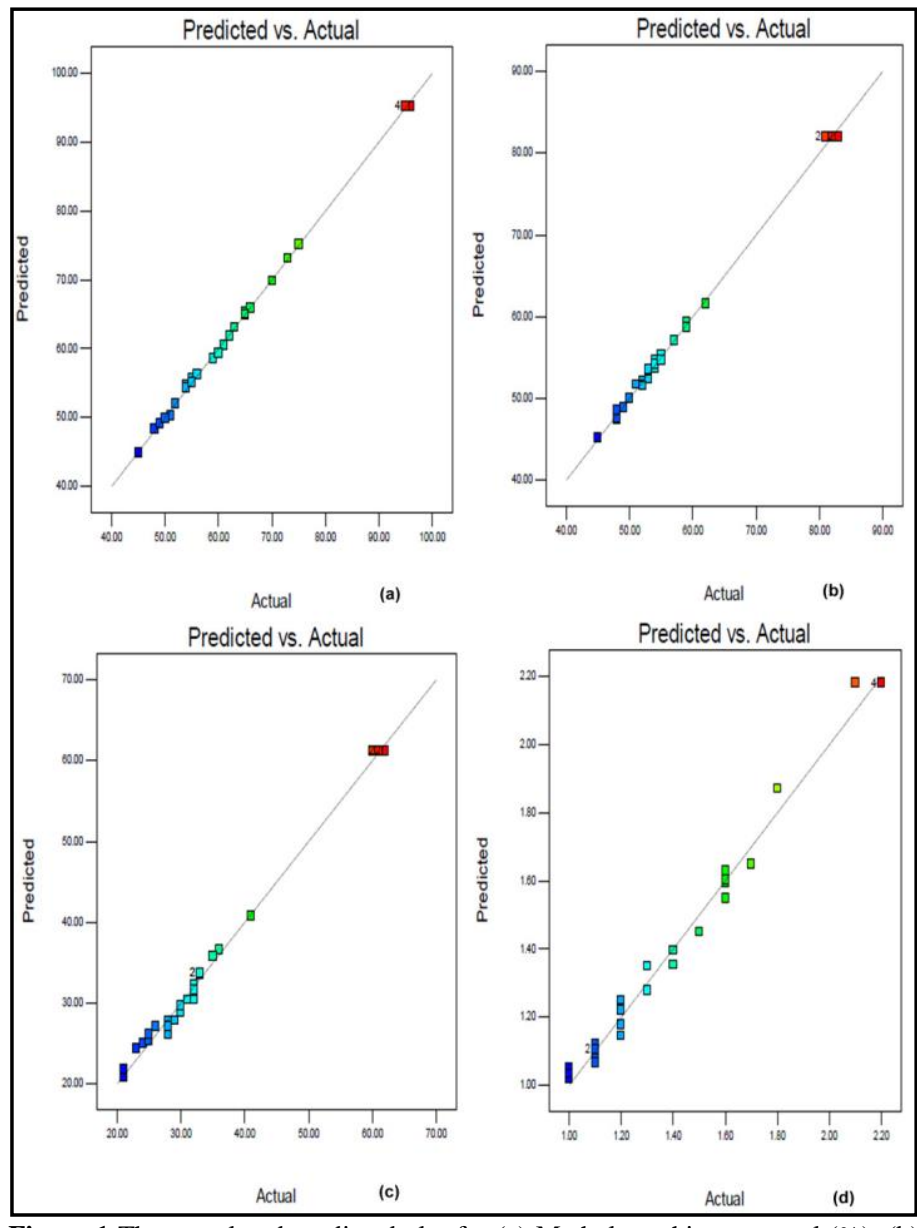

Figure 1 The actual and predicted plot for (a) Methylparathion removal (\%), (b) COD removal (\%), (c) TOC removal (\%) and (d) growth (OD)

\section{Analysis of optimized process variables by response surface plots}

The optimum values of the selected variables were obtained by solving their regression equation and analyzing response surface contour plots. Response Surface plots as a function of four factor at a time maintaining all other factors at a fixed level (zero for instance) are more helpful in understanding both the main and interaction effects of the four factors. The plots can be easily obtained by calculating the data from the model. The values were taken by one factor, where the second varies with constant of a given Y-values. The yield values of the different concentrations and range of the variable can also be predicted from respective response surface plots. The coordinates of the central point within the highest optimum concentration of the respective components. Figures 2 to 5 show their response surface obtained as a function of temperature, $\mathrm{pH}$, time and agitation against methylparathion removal, COD removal, TOC removal and growth of bacteria in terms of optical density.

\section{Optimum values and validation of the model}

The methylparathion removal by Pseudomonas aeruginosa mpd was predominantly influenced by the combined effects of the environmental factors include temperature, $\mathrm{pH}$, incubation period (time) and agitation. The point prediction from the analysis of variables for the response surface model showed the maximum methylparathion removal $(95.2 \%)$, COD removal $(82 \%)$, TOC removal $(61.2 \%)$ and growth $(2.18 \mathrm{OD})$ by Pseudomonas aeruginosa (mpd) in synthetic wastewater containing $1000 \mathrm{mgL}^{-1}$ of methylparathion at optimum conditions of $\mathrm{pH}(7)$, temperature $\left(32.5^{\circ} \mathrm{C}\right)$ and agitation at $150 \mathrm{rpm}$ for $96 \mathrm{~h}$ of incubation period. As can be seen, there is not much difference between the experimental values and model response values obtained. This confirmed that RSM could be effectively used to predict the removal performance of methylparathion from wastewater by potential bacterial strain (Pseudomonas aeruginosa mpd).

The maximum experimental response for methylparathion removal was $95 \%$ whereas the predicted value was $95.2 \%$ indicating a strong agreement between them. The optimum values of the tested variables are at $\mathrm{pH} 7,32.5^{\circ} \mathrm{C}$ temperature and agitation at $150 \mathrm{rpm}$ for $96 \mathrm{~h}$ of incubation time as shown in perturbation graph (Figure 6.). The model was also validated by conducting the experiments under the optimized conditions, which resulted in the methylparathion removal of $96 \%$ (Predicted response $95.2 \%$ ), thus proving the validity of the model.

The temperature is the most suitable variable for the growth of the isolates as well as the methylparathion (MP) removal which was found to be growth related processes. Temperature is another abiotic factor that influences the rate and extent of bioremediation since it affects microbial activity with rates of metabolic reactions generally increasing with increasing temperature (Baker, 1994 and Hong et al., 2007). Shake culture or aerated culture conditions are better for the growth and removal of methylparathion. The rise in temperature of the synthetic wastewater medium may accelerate the chemical reactions, reduces solubility of gases, amplifies taste and odour and elevates metabolic activity of organisms. This in turns reduce the organic loads in terms of COD and TOC in the wastewater. The decrease in COD and TOC may increase the biodegradation of methylparathion. This may be the cause for the increase in the biodegradability of methylparathion from the medium. So, the organic loads in terms of these parameters may increase the removal of methylparathion from aqueous solution. It was noted that the removal of organic load in terms of COD was proportional to the disappearance of cypermethrin (Jilani and Khan, 2006). Similar correlations were also observed by Berchtold et al., (1995).

The optimum growth of the strain was found to be $\mathrm{pH} \mathrm{7.} \mathrm{The} \mathrm{strain} \mathrm{mpd} \mathrm{can}$ degrade methylparathion from $\mathrm{pH} 7$; this could perhaps be due to increased bioavailability of methylparathion and optimal biotic activity of cells in this $\mathrm{pH}$ The $\mathrm{pH}$ from 5 to 8 suggested that dissipation of methylparathion was mediated by the cometabolic activities of the bacteria and also the rate of degradation of methylparathion was low in acidic but increased considerably with an increase in pH. Brajesh et al., (2004) also reported similarly that the pH from 4.7 to 8.4 for chlorpyrifos by Enterobacter strain (B-14). The optimum conditions were more favorable for the growth of the bacteria. It may be either metabolize or cometabolize the methylarathion in the medium as a nutrient or energy source for their growth and metabolism. The degradation of methylparathion supported cell growth, indicating that isolated strain could utilize methylparathion as a phosphorus source. The $\mathrm{pH}$ condition would be significance while emergent an effective remediation strategy.

The optimum time for the incubation period was enhanced the growth of the bacteria and increase its metabolic activity. The log phase of the bacteria was extended and the secondary metabolites which include the release of the respective enzymes responsible for the hydrolysis of methylparathion degradation, or oxidation and reduction process may occur. This in turns may results in the higher reactivity of the pollutant and increases the degradation process. The optimum agitation observed was more encouraged for the growth of the bacteria by utilizing the nutrients from the uniformly distributed and suspended nutrients in the medium which may helps in oxidation process. It may be either metabolize or co-metabolize the methylarathion in the medium. Shake culture or aerated culture conditions are better for the growth and removal of methylparathion. Methylparathion removal under aerobic conditions suggesting that a constitutively expressed enzyme could be involved in the degradation. Repeated application of pesticides results in the enhanced ability of microbial population to degrade the pesticide. The study also suggests that methylparathion degrading bacterial culture should preferably be used for the management of methylparathion containing wastewater. 
J Microbiol Biotech Food Sci / Usharani et al. 2016 : 5 (6) 534-547

Table 4 ANOVA table for $\mathrm{Y}_{1}$ (methylparathion removal in \%), $\mathrm{Y}_{2}$ (COD removal in \%), $\mathrm{Y}_{3}$ (TOC removal in \%) and $\mathrm{Y}_{4}$ (growth in optical density) responses

\begin{tabular}{|c|c|c|c|c|c|c|c|c|c|c|c|c|c|c|c|c|c|}
\hline \multirow{2}{*}{ Source } & \multirow{2}{*}{ DF } & \multicolumn{4}{|c|}{$Y_{1}$} & \multicolumn{4}{|c|}{$\mathbf{Y}_{2}$} & \multicolumn{4}{|c|}{$\mathbf{Y}_{3}$} & \multicolumn{4}{|c|}{$\mathbf{Y}_{4}$} \\
\hline & & SS & MS & $\mathbf{F}$ & $\mathbf{P}$ & SS & MS & $F$ & $\mathbf{P}$ & SS & MS & $F$ & $\mathbf{P}$ & SS & MS & $\mathbf{F}$ & $\mathbf{P}$ \\
\hline Model & 14 & 6903 & 493 & 1857 & $<0.0001$ & 3961 & 282 & 522 & $<0.0001$ & 4683 & 334 & 202 & $<0.0001$ & 4.55 & 0.32 & 117 & $<0.0001$ \\
\hline A- $\mathbf{X}_{1}-\operatorname{Temp}\left({ }^{\circ} \mathrm{C}\right)$ & 1 & 261 & 261 & 984 & $<0.0001$ & 6.7 & 6.7 & 12.4 & 0.0033 & 18.7 & 18.7 & 11.3 & 0.0046 & 0.06 & 0.06 & 24.3 & 0.0002 \\
\hline B- $\mathbf{X}_{2-}-\mathbf{p H}$ & 1 & 90.7 & 90.7 & 341 & $<0.0001$ & 75 & 75 & 138 & $<0.0001$ & 80 & 80 & 48.4 & $<0.0001$ & 0.21 & 0.21 & 76.9 & $<0.0001$ \\
\hline C-X $\mathbf{X}_{3}$ - Time (h) & 1 & 396 & 396 & 1494 & $<0.0001$ & 21.3 & 21.3 & 39.3 & $<0.0001$ & 10 & 10 & 6.1 & 0.0270 & 0.18 & 0.18 & 67.5 & $<0.0001$ \\
\hline D- $\mathrm{X}_{4}-$ Agitation (rpm) & 1 & 85.3 & 85.3 & 321 & $<0.0001$ & 80 & 80 & 147 & $<0.0001$ & 36.7 & 36.7 & 22.2 & 0.0003 & 0.16 & 0.16 & 58.8 & $<0.0001$ \\
\hline $\mathbf{X}_{1} \mathbf{X}_{2}$ & 1 & 1 & 1 & 3.76 & 0.0727 & 9 & 9 & 16.6 & 0.0011 & 0.25 & 0.25 & 0.15 & 0.7032 & 0.00 & 0.00 & 0.90 & 0.3585 \\
\hline $\mathbf{X}_{1} \mathbf{X}_{3}$ & 1 & 72.2 & 72.2 & 272 & $<0.0001$ & 4 & 4 & 7.38 & 0.0167 & 20.2 & 20.2 & 12.2 & 0.0035 & 0.00 & 0.00 & 0.90 & 0.3585 \\
\hline $\mathbf{X}_{1} \mathbf{X}_{4}$ & 1 & 240 & 240 & 904 & $<0.0001$ & 72.2 & 72.2 & 133 & $<0.0001$ & 90.2 & 90.2 & 54.6 & $<0.0001$ & 0.12 & 0.12 & 44.1 & $<0.0001$ \\
\hline $\mathbf{X}_{2} \mathbf{X}_{3}$ & 1 & 81 & 81 & 305 & $<0.0001$ & 4 & 4 & 7.38 & 0.0167 & 72.2 & 72.2 & 43.7 & $<0.0001$ & 0.25 & 0.25 & 90.1 & $<0.0001$ \\
\hline $\mathbf{X}_{2} \mathbf{X}_{4}$ & 1 & 20.2 & 20.2 & 76.2 & $<0.0001$ & 4 & 4 & 7.38 & 0.0167 & 20.2 & 20.2 & 12.2 & 0.0035 & 0.06 & 0.06 & 22.5 & 0.0003 \\
\hline $\mathbf{X}_{3} \mathbf{X}_{4}$ & 1 & 36 & 36 & 135 & $<0.0001$ & 25 & 25 & 46.1 & $<0.0001$ & 6.25 & 6.25 & 3.7 & 0.0722 & 0.09 & 0.09 & 32.4 & $<0.0001$ \\
\hline $\mathbf{X}_{1}^{2}$ & 1 & 2808 & 2808 & 10579 & $<0.0001$ & 1138 & 1138 & 2102 & $<0.0001$ & 1655 & 1655 & 1001 & $<0.0001$ & 0.92 & 0.92 & 333 & $<0.0001$ \\
\hline $\mathbf{X}_{2}{ }^{2}$ & 1 & 2144 & 2144 & 8078 & $<0.0001$ & 914 & 914 & 1688 & $<0.0001$ & 1050 & 1050 & 635 & $<0.0001$ & 1.25 & 1.25 & 452 & $<0.0001$ \\
\hline $\mathbf{X}_{3}{ }^{2}$ & 1 & 2387 & 2387 & 8991 & $<0.0001$ & 1583 & 1583 & 2923 & $<0.0001$ & 1553 & 1553 & 940 & $<0.0001$ & 0.92 & 0.92 & 333 & $<0.0001$ \\
\hline $\mathbf{X}_{4}{ }^{2}$ & 1 & 1327 & 1327 & 5002 & $<0.0001$ & 1986 & 1986 & 3667 & $<0.0001$ & 2397 & 2397 & 1450 & $<0.0001$ & 2.07 & 2.07 & 746 & $<0.0001$ \\
\hline Residual & 14 & 3.71 & 0.26 & & & 7.58 & 0.54 & & & 23.1 & 1.67 & & & 0.03 & 0.00 & & \\
\hline Lack of Fit & 10 & 2.91 & 0.29 & 1.458 & 0.3821 & 3.58 & 0.36 & 0.36 & 0.9143 & 20.3 & 2.0 & 2.9 & 0.157 & 0.03 & 0.00 & 1.54 & 0.3594 \\
\hline Pure Error & 4 & 0.8 & 0.2 & & & 4 & 1 & & & 2.8 & 0.7 & & & 0.00 & 0.00 & & \\
\hline Cor Total & 28 & 6906 & & & & 3968 & & & & 4706 & & & & 4.59 & & & \\
\hline
\end{tabular}


Table 5 Analysis of variance (A NOVA) results of the model of methylparathion removal, COD and TOC removal by Pseudomonas aeruginosa mpd

\begin{tabular}{|c|c|c|c|c|c|c|c|}
\hline Source & $\begin{array}{l}\text { Sum } \\
\text { squares }\end{array}$ & of & $\begin{array}{l}\text { Degree of } \\
\text { freedom }\end{array}$ & $\begin{array}{l}\text { Mean } \\
\text { Square }\end{array}$ & F-value & $\begin{array}{l}\text { Prob } \\
>\text { F }\end{array}$ & Remarks \\
\hline \multicolumn{8}{|c|}{ a'MP-Removal (\%) } \\
\hline Model & 6903 & & 14 & 493.07 & 1857.3 & $<0.0001$ & Significant \\
\hline Residual & 3.716 & & 14 & 0.2654 & & & \\
\hline Lack of fit & 2.916 & & 10 & 0.2916 & 1.4583 & 0.3821 & Not- Significant \\
\hline Pure error & 0.8 & & 4 & 0.2 & & & \\
\hline Cor Total & 6906 & & 28 & & & & \\
\hline \multicolumn{8}{|c|}{${ }^{\mathrm{b}}$ COD Removal (\%) } \\
\hline Model & 3961 & & 14 & 282.94 & 522.3 & $<0.0001$ & Significant \\
\hline Residual & 7.58 & & 14 & 0.54 & & & \\
\hline Lack of fit & 3.58 & & 10 & 0.36 & 0.36 & 0.9143 & Not- Significant \\
\hline Pure error & 4.00 & & 4 & 1.00 & & & \\
\hline Cor Total & 3968 & & 28 & & & & \\
\hline \multicolumn{8}{|c|}{${ }^{\mathrm{c}}$ TOC Removal (\%) } \\
\hline Model & 4683 & & 14 & 334.55 & 202.47 & $<0.0001$ & Significant \\
\hline Residual & 23.13 & & 14 & 1.6523 & & & \\
\hline Lack of fit & 20.33 & & 10 & 2.0333 & 2.9047 & 0.1579 & Not- Significant \\
\hline Pure error & 2.8 & & 4 & 0.7 & & & \\
\hline Cor Total & 4706 & & 28 & & & & \\
\hline \multicolumn{8}{|l|}{${ }^{\mathrm{d}} \mathbf{G}-\mathbf{M P}^{+}(\mathbf{O D})$} \\
\hline Model & 4.553 & & 14 & 0.3252 & 117.25 & $<0.0001$ & Significant \\
\hline Residual & 0.038 & & 14 & 0.0027 & & & \\
\hline Lack of fit & 0.030 & & 10 & 0.0030 & 1.5416 & 0.3594 & Not- Significant \\
\hline Pure error & 0.008 & & 4 & 0.002 & & & \\
\hline Cor Total & 4.592 & & 28 & & & & \\
\hline 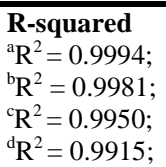 & $\begin{array}{c}\text { Adj R-squared } \\
R^{2}{ }_{\text {adj }}=0.9989 ; \\
R^{2}{ }_{\text {adj }}=0.9962 ; \\
R^{2}{ }_{\text {adj }}=0.9901 ; \\
R^{2}{ }_{\text {adj }}=0.9830\end{array}$ & & $\begin{array}{l}\text { ed R-squared } \\
\mathrm{pred}=0.9973 \\
\mathrm{pred}=0.9932 \\
\mathrm{pred}=0.9741 \\
\mathrm{pred}=0.9586\end{array}$ & $\begin{array}{l}\text { Adequ: } \\
\text { Adeq pr } \\
\text { Adeq pr } \\
\text { Adeq pr } \\
\text { Adeq pr }\end{array}$ & $\begin{array}{l}\text { ecision } \\
n=135.92 \\
n=69.66 \\
n=43.75 \\
n=30.60\end{array}$ & & \\
\hline
\end{tabular}

MP-Methylparathion, COD-Chemical oxygen demand, TOC-Total organic carbon,

$\mathbf{G}-\mathbf{M P}^{+}$- Growth in presence of methylparathion, $\mathrm{OD}$ - Optical density 


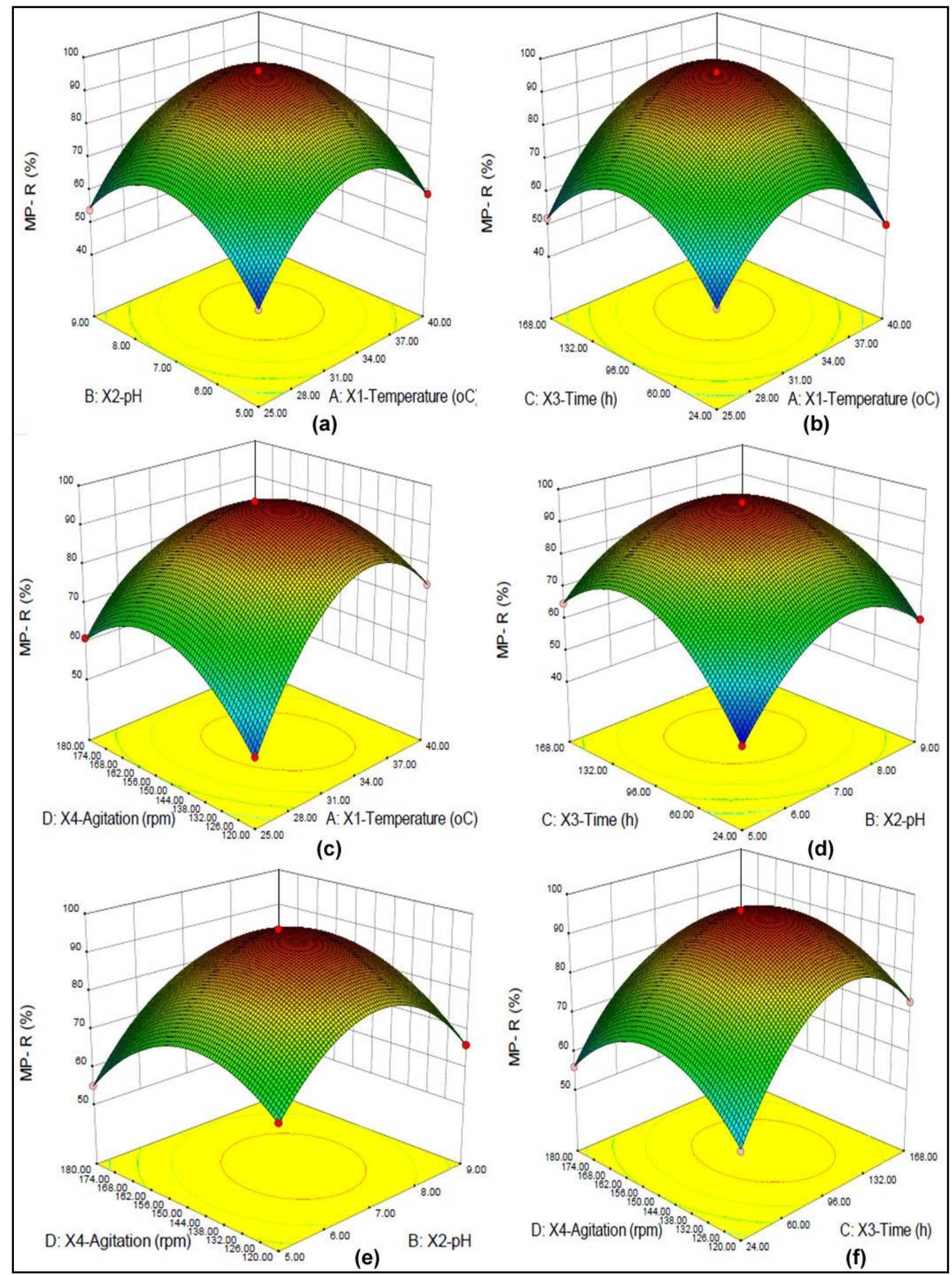

Figure 2a Response surface plot of the combined effects of $\mathrm{pH}$, temperature, time and agitation on the percentage removal of Methylparathion by Pseudomonas aeruginosa mpd 


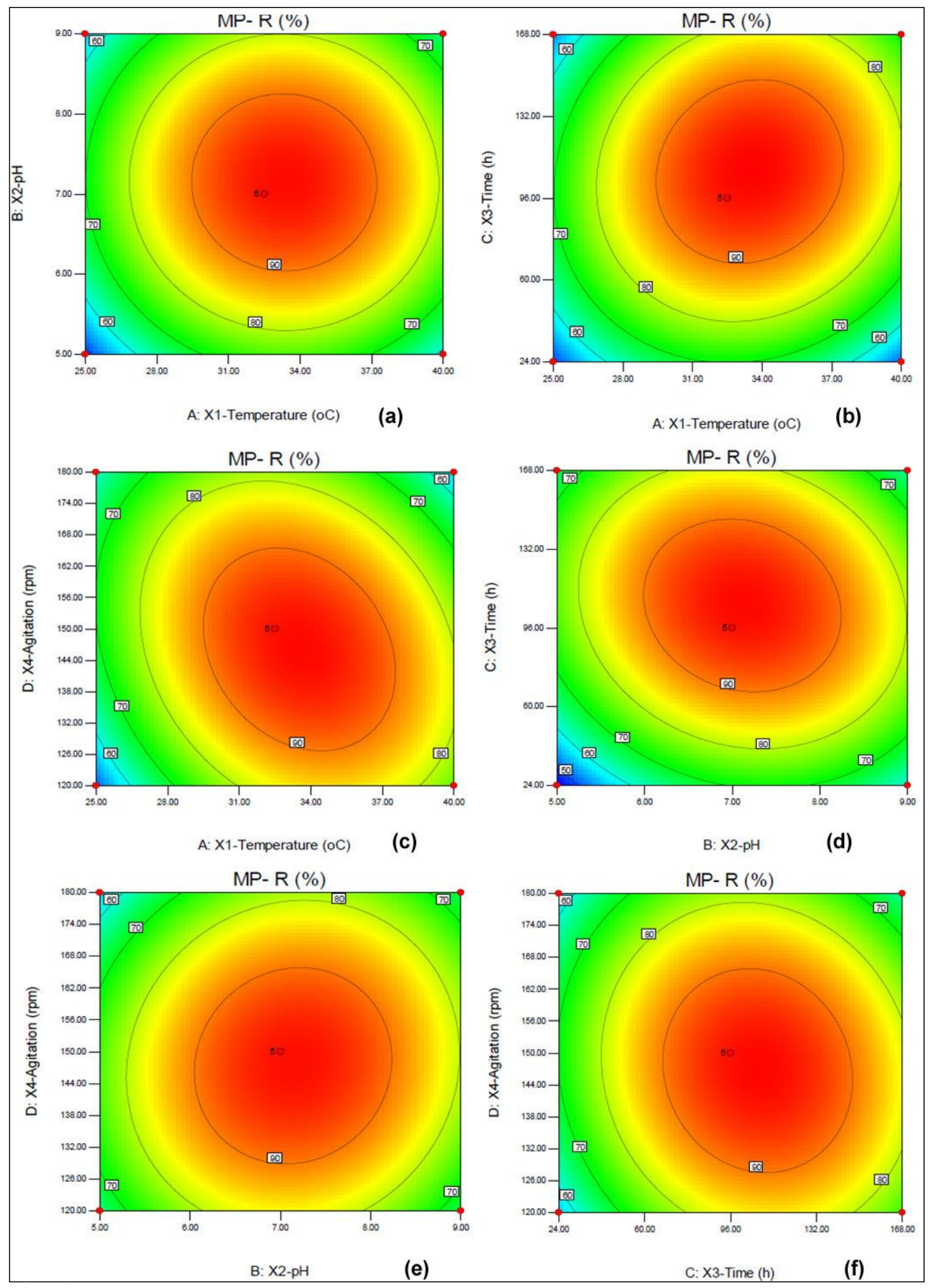

Figure 2b Contour surface plot of the combined effects of $\mathrm{pH}$, temperature, time and agitation on the percentage removal of Methylparathion by Pseudomonas aeruginosa mpd 


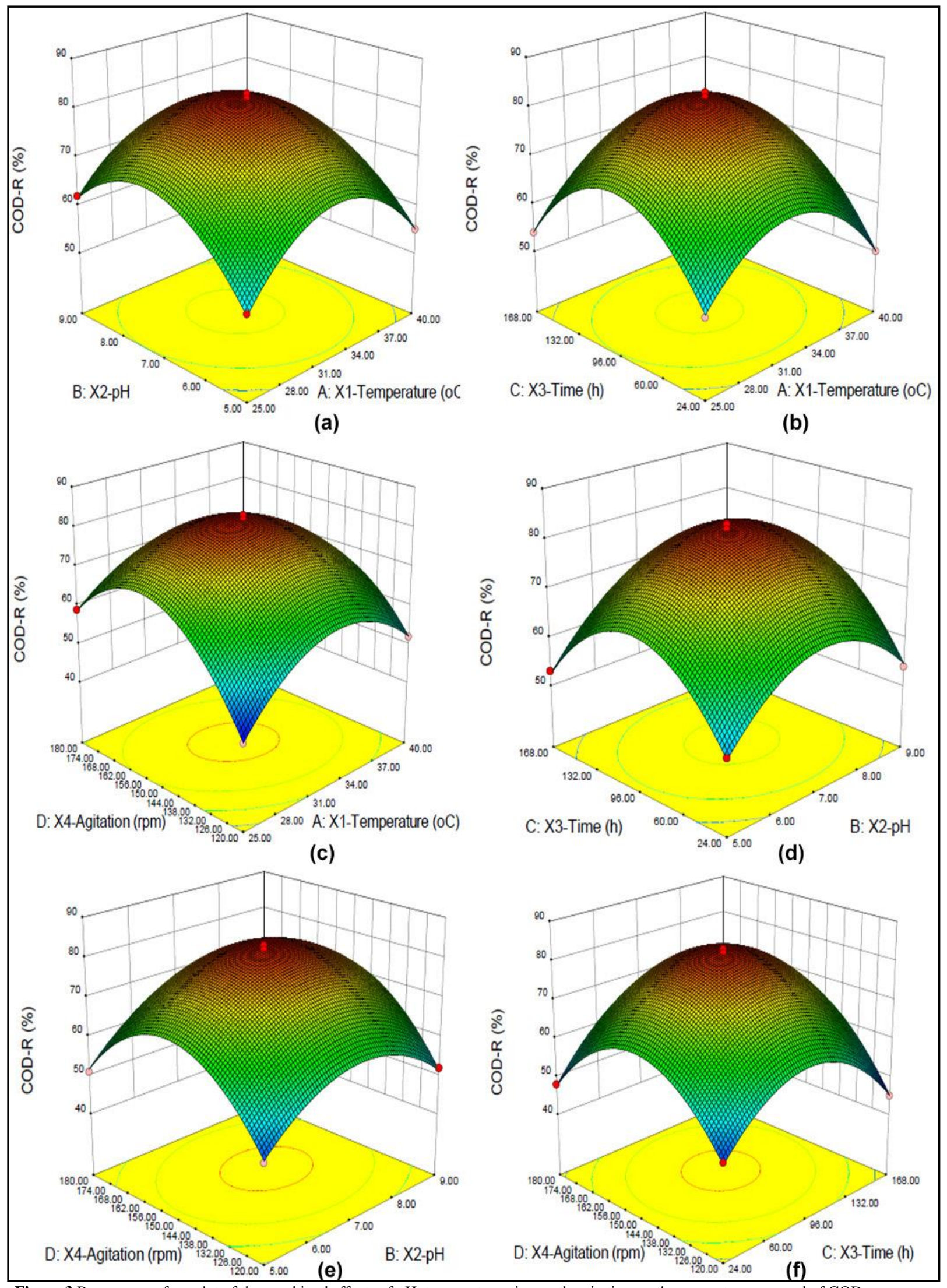

Figure 3 Response surface plot of the combined effects of $\mathrm{pH}$, temperature, time and agitation on the percentage removal of COD by Pseudomonas aeruginosampd 


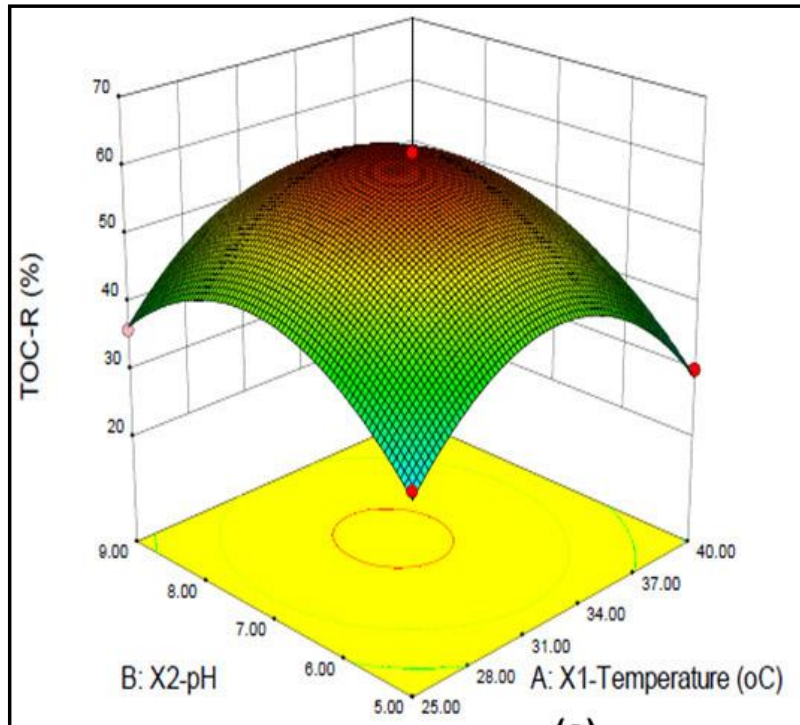

(a)

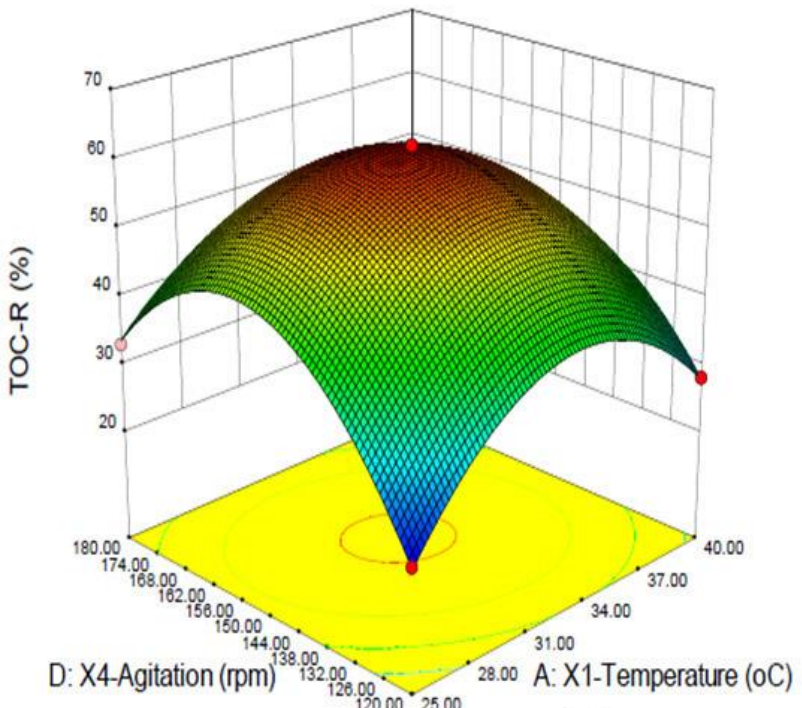

(c)

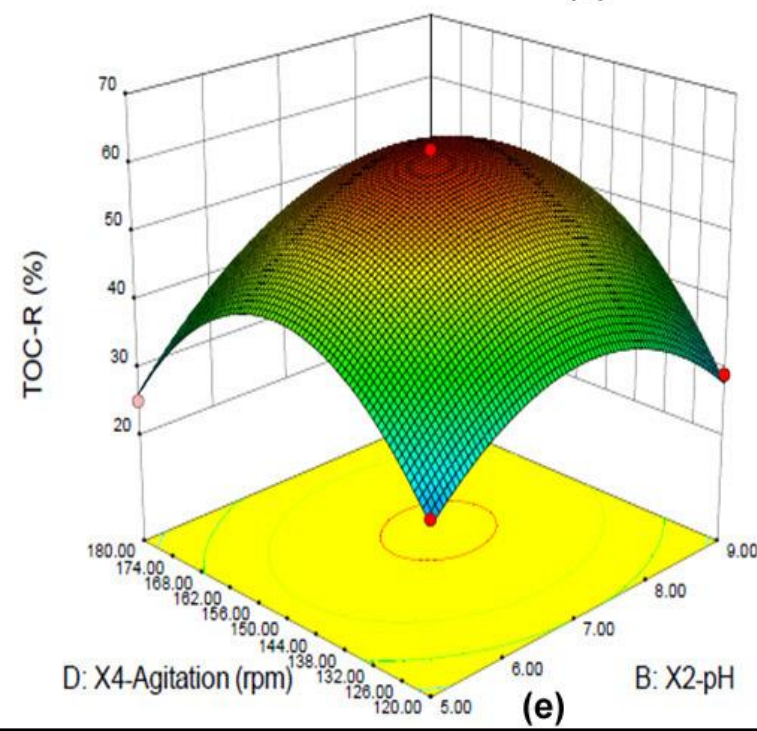

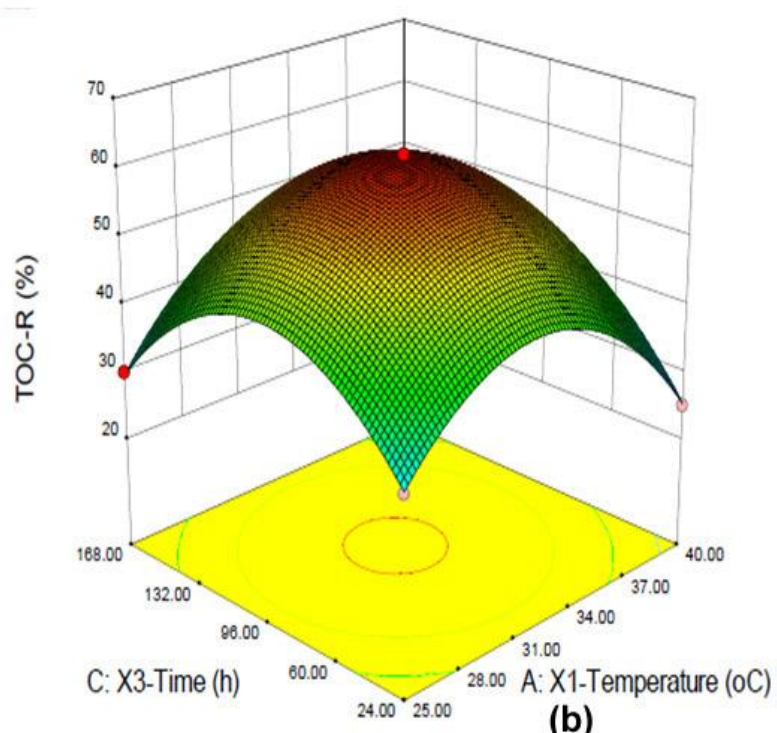

(b)

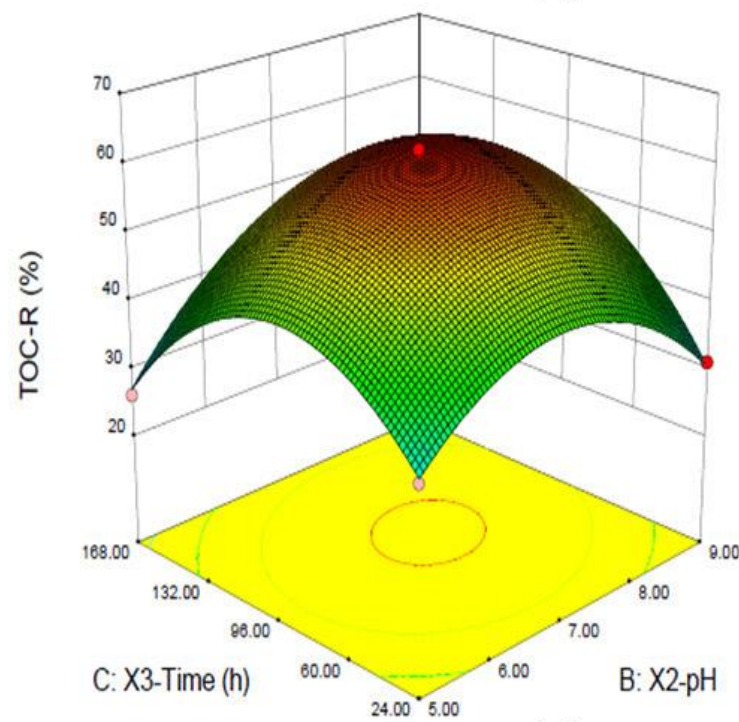

(d)

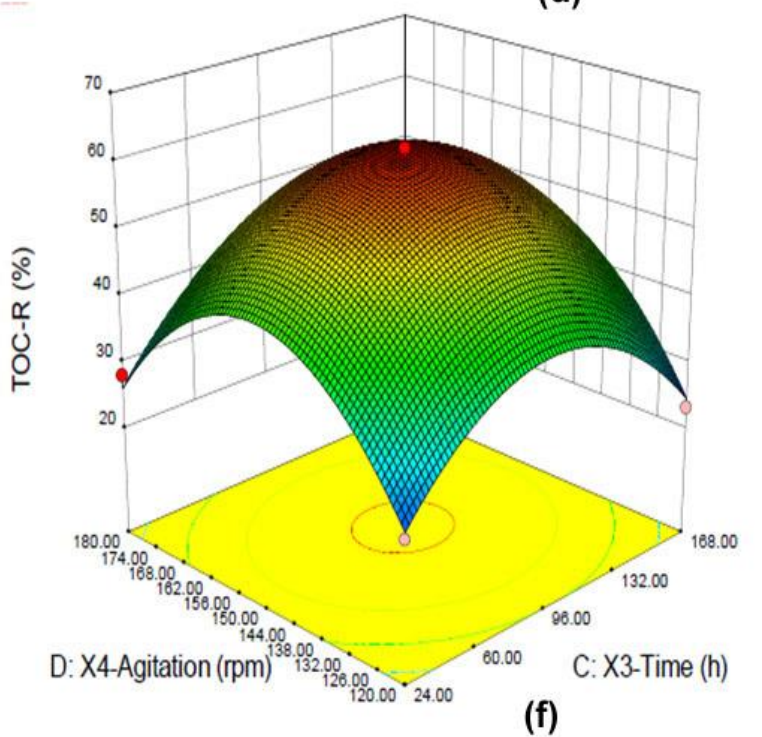

Figure 4 Response surface plot of the combined effects of $\mathrm{pH}$, temperature, time and agitation on the percentage removal of TOC by Pseudomonas aeruginosa mpd 


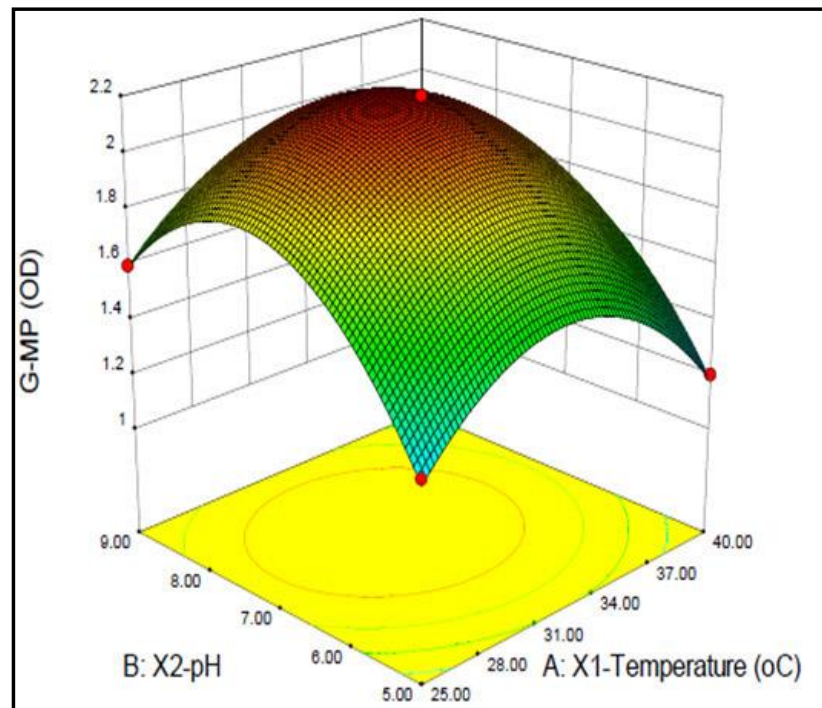

(a)

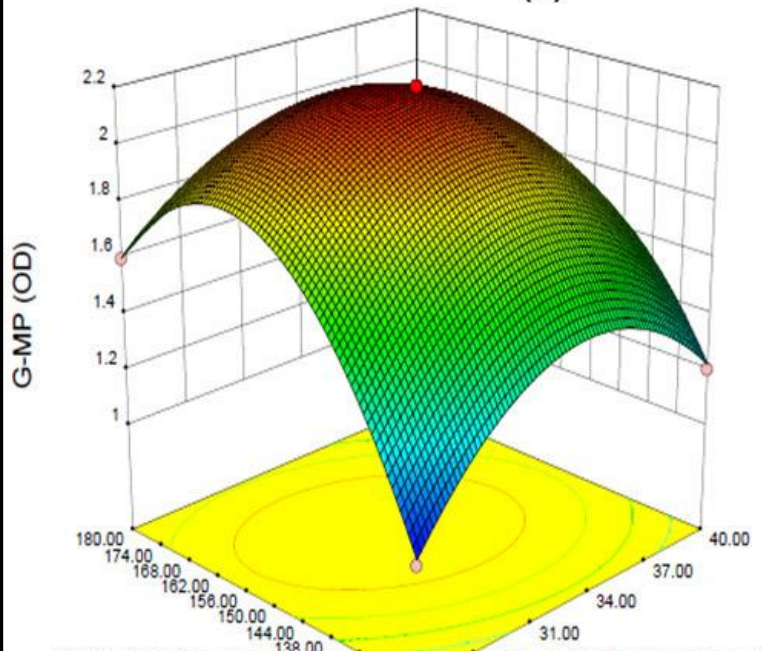

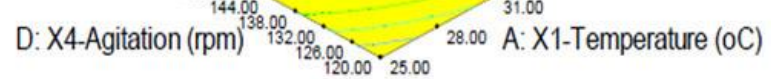

(c)

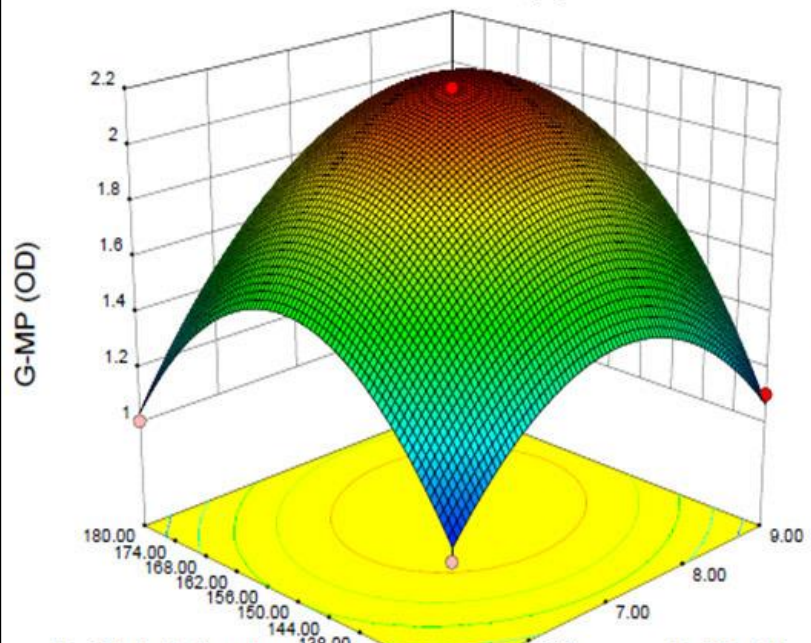

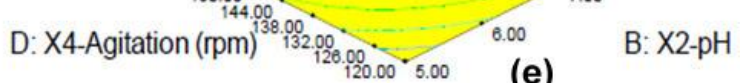

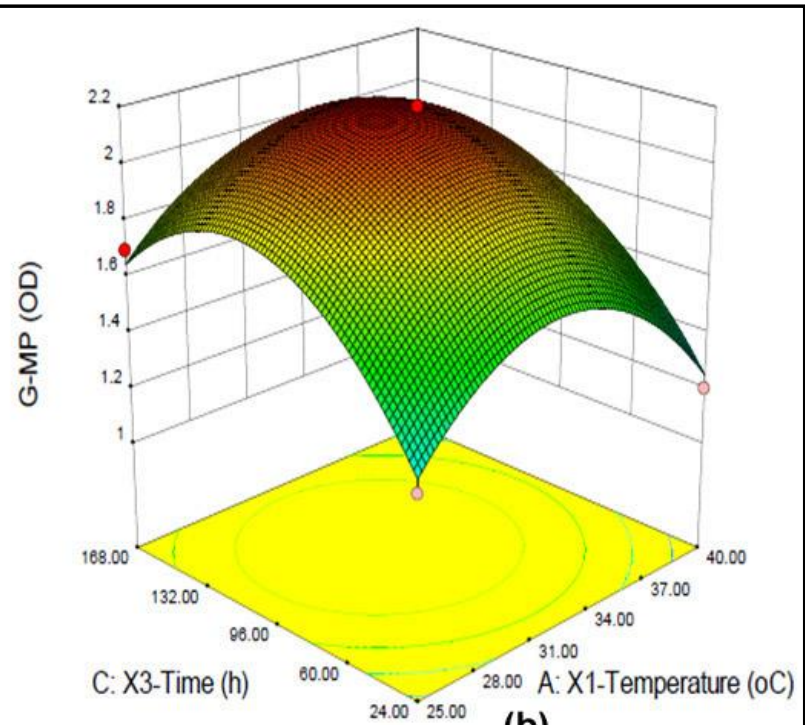

(b)

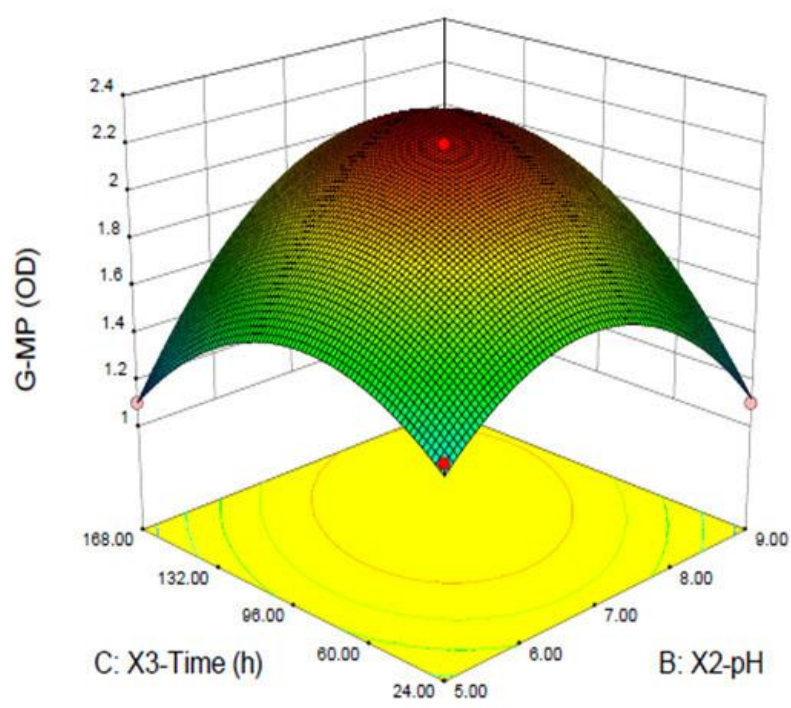

(d)

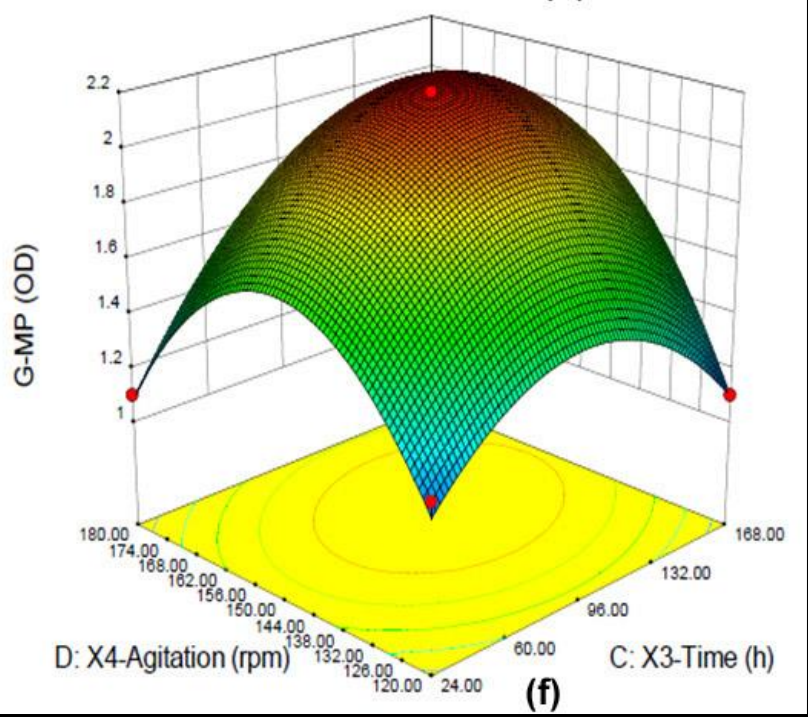

(f)

Figure 5 Response surface plot of the combined effects of $\mathrm{pH}$, temperature, time and agitation on the growth of Pseudomonas aeruginosa $\mathrm{mpd}$ 

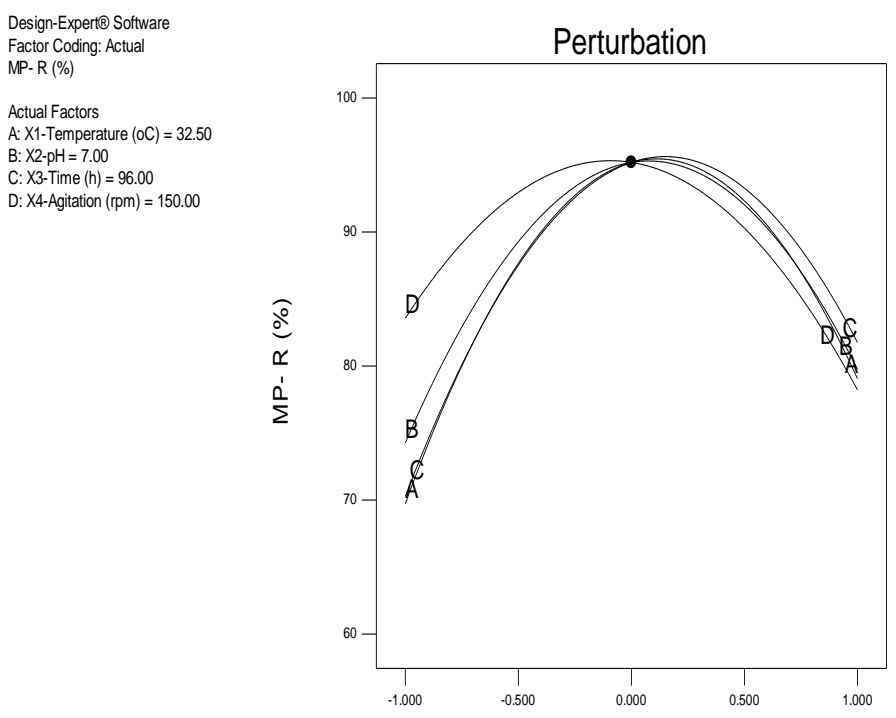

Deviation from Reference Point (Coded Units)

Figure 6 Perturbation graph showing the optimum values of the tested variables

However, in the presence of other carbon sources (such as glucose), initially it delayed to degrade methylparathion but with the passage of time it degraded to $95 \%$ within $96 \mathrm{~h}$, indicating that when glucose was depleted, it started to utilize methylparathion as a source of carbon. Similar results were reported by Brajesh et al., (2004). Glucose was chosen because it is a primarily substratum and the main carbon source for the bacteria. Glucose addition is important to improve the efficacy of bioremediation of persistent compounds like pesticides (Sampaio, 2005; Singh, 2006; Yang et al., 2009; Yugui et al., 2008). Qiu et al., (2006) reported that the additional nutrients such as glucose and organic nitrogen greatly enhanced the growth of Ochrobactrum sp B2. Singh (2006), reports that the addition of glucose produces substances of high reactivity, which react more easily with the pollutant. Previous reports concerning isolation of organophosphorus degrading microorganisms suggest that the bacteria mainly degrade the compounds cometabolically (Horne et al., 2002; Zhongli et al., 2001). Some reports showed that the isolated bacterium can utilize organophosphates as a source of carbon or phosphorus (Subhas and Dileep, 2003) from the hydrolysis products (Serdar and Gibson, 1985). In natural environments, the competition for carbon sources is immense and the utilization of pesticide as an energy source by this bacterium provides it with a substantial competitive advantage over other microorganisms (Malghani et al., 2009).

\section{UV-Vis Spectral Analysis}

In order to investigate the formation and eventual disappearance of intermediate compounds in the reaction mixture, the biotreated synthetic wastewater containing methylparathion was monitored using UV-Vis spectroscopy as a function of time. The UV-Vis spectroscopy scanning profile shows a peak formation with lambda $\max (\lambda \max )$ at $277 \mathrm{~nm}$ as shown in Figure 7 . The extended biotreatment after $96 \mathrm{~h}$ shows the same band decrease its intensity and eventually disappeared. The absorbance value was found to be reduced at maximum time of $96 \mathrm{~h}$ at optimized process variables. The wavelength at $277 \mathrm{~nm}$ shows a displacement to higher wavelengths and formation of band at $400 \mathrm{~nm}$ that can be attributed to the p-nitrophenol absorption bands. Zhongli et al (2001) reported that the maximum absorption peak of methylparathion was recorded at 273nm by Plesiomonas strain (M6). Wu and Linden (2008) reported that the parathion produces a maximum absorbance $(\lambda \max )$ at $275 \mathrm{~nm}$. Further, the biotreated samples were analysed by HPLC for the confirmation of the residual MP and intermediates formation.

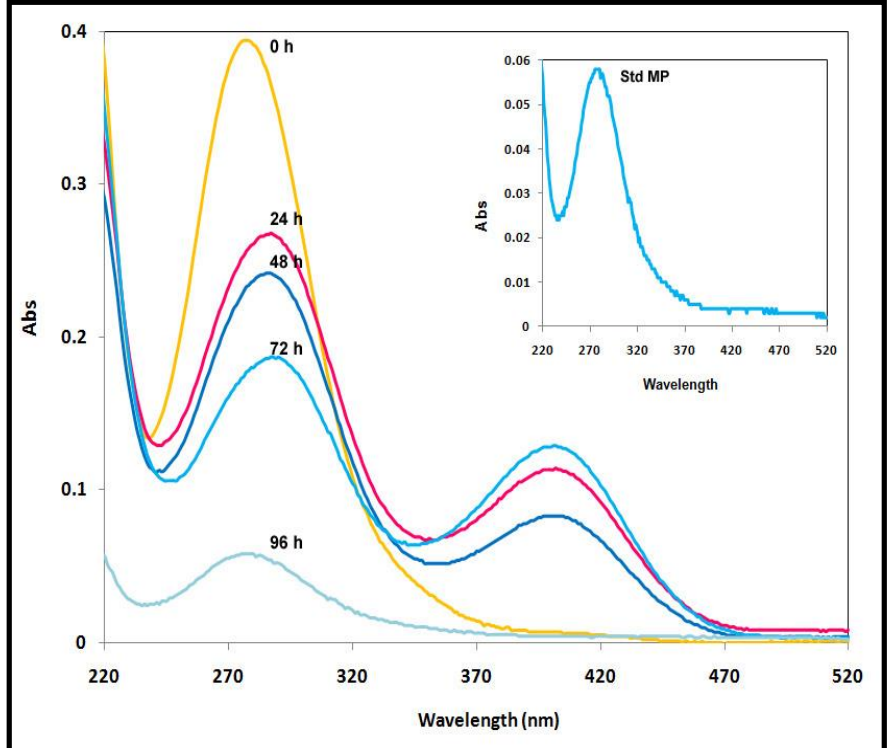

Figure 7 UV -Vis NIR Spectroscopic scanning profile of MP degradation by Pseudomonas aeruginosa mpd at different treatment time (h)

\section{HPLC Analysis}

The biotreated samples were analysed by HPLC for the confirmation of the residual methylparathion and their byproducts or intermediatediates formation. The retention time for methylparathion was found to be $3.3 \mathrm{~min}$ which was confirmed by the spectra as shown in Figure 8. The percentage degradation of methylparathion by Pseudomonas aeruginosa mpd was found to be $95 \%$. Treated samples showed that the peak reduction at 3.3 retention time (RT), hence it proves the degradation of methylparathion by biotreatment (Pseudomonas aeruginosa mpd) process. The peak at retention time of 4.0, 4.4 and $10 \mathrm{~min}$ in treated sample were observed as the intermediate products of methylparathion degradation during the biotreatment process. Moreover, methylparathion was rapidly oxidized into other organic compounds.

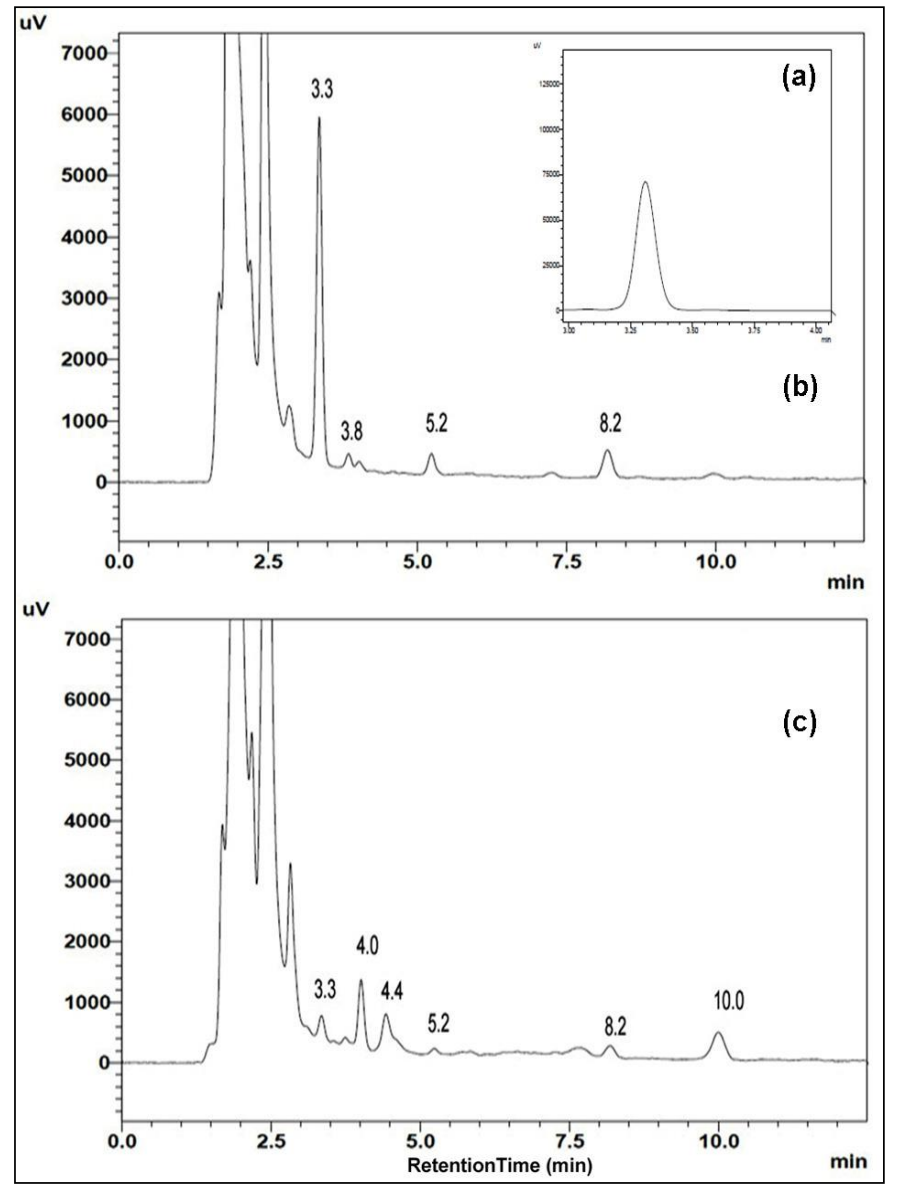

Figure 8 HPLC profiles of methylparathion biodegradation by Pseudomonas aeruginosa mpd after 72h (a) Standard, (b) Control and (b) Treated after $72 \mathrm{~h}$ 


\section{CONCLUSION}

RSM was used in this study to establish the optimum variables initial $\mathrm{pH}$, time, culture temperature and agitation for methylparathion biodegradation. It was concluded that the optimal conditions for methylparathion removal are $\mathrm{pH} 7$ and $32.5{ }^{\circ} \mathrm{C}$ temperature and agitation at $150 \mathrm{rpm}$ for $96 \mathrm{~h}$ of incubation period. The predicted extent of methylparathion biodegradation by this strain of Pseudomonas aeruginosa under these optimum conditions was $95.2 \%$, and the experimental results were in close agreement with this prediction. The point prediction from the analysis of variable for response surface model for methylparathion removal (95.2\%), COD removal (82\%), (c) TOC removal (61.2 $\%)$ and (d) growth (2.18 OD) by Pseudomonas aeruginosa (mpd) from waste water with $1000 \mathrm{mg} / \mathrm{L}$ of medium at optimum conditions of $\mathrm{pH}$, temperature and agitation for $96 \mathrm{~h}$ of incubation period. The predicted optimal and experimenta measured methylparathion removal efficiencies agreed well with high coefficients of determination $\left(\mathrm{R}^{2}=0.9994, \mathrm{R}^{2}\right.$ adj $\left.=0.9989\right)$, and the COD removal $\left(\mathrm{R}^{2}=0.9981 \mathrm{R}^{2}\right.$ adj $\left.=0.9962\right)$ and TOC removal $\left(\mathrm{R}^{2}=0.9950, \mathrm{R}^{2}\right.$ adj $\left.=0.9901\right)$ are also agreed well. Moreover the growth of the strain in terms of its OD were also agreed well $\left(\mathrm{R}^{2}=0.9915, \mathrm{R}^{2}\right.$ adj $\left.=0.9830\right)$. Hence this study was an attempt for methylparathion removal using Pseudomonas aeruginosa strain with RSM model, has helped to recognize the important operating variables and optimum levels with least effort and time. The isolate of the present study was found to have potential in methylparathion removal at optimized condition and suggested for biotreatment of methylparathion wastewater. This study will form the basis for the further utilization of the bacterial strain, grown on suitable substrates, in biofiltration systems for the treatment of wastewaters.

Acknowledgments: The author Ms. K. Usharani expresses her sincere thanks to the editor and anonymous reviewers for present the research paper in a professional manner.

Conflict of interest: The authors declare no conflict of interest.

\section{REFERENCES}

American Public Health Association In: Standard Methods for the Examination of Water and Wastewater, 20th ed. APHA, Washington, DC.1998. http://dx.doi.org/10.5860/choice.37-2792

BAKER, K.H. 1994. Bioremediation of surface and subsurface soils, in: Baker KH, Herson DS (eds), Bioremediation. McGraw-Hill, Inc., 209-259.

BERCHTOLD, S.R., VANDERLOOP, S.L., SUIDAN, M.T., MALONEY, S.W., 1995. Treatment of 2,4-diaminotoluene using a two stage system: fluidized-bed anaerobic granular activated carbon reactor. Wat.Environ.Res., 67:1081 1091. http://dx.doi.org/10.2175/106143095x133338

BHADBHADE, B.J., SARNAIK, S.S., KANEKAR, P.P., 2002. Bioremediation of an industrial effluent containing monocrotophos. Curr Microbiol., 45:345-349. http://dx.doi.org/10.1007/s00284-002-3681-1

BOX, G.E.P., BEHNKEN, D.W., 1960. Some new three level designs for the study of quantitative variables. Technometrics., 2: 455-475. http://dx.doi.org/10.1080/00401706.1960.10489912

BRAJESH, K.S., WALKER, A., ALUN, W., DENIS, J.W., 2004. Biodegradation of chlorpyrifos by Enterobacter strain B-14 and its use in bioremediation of contaminated soils. Appl Environ Microbiol., 70(8): 4855-4863. http://dx.doi.org/10.1128/aem.70.8.4855-4863.2004

CHIRON, S, FERNANDEZ ALBA, A.R., RODRIGUEZ, A., 1997. Trends in analytical Chemistry, Vol.16.No.9, Elsevier Sciences., PIIS0165-9936 (97) 00078-2. http://dx.doi.org/10.1016/s0165-9936(97)00078-2

CISAR, J.L., SNYDER, G.H., 2000. Fate and management of turfgrass chemicals, ACS Symp, Series., 743:106-126. http://dx.doi.org/10.1021/bk-20000743.fw001

COUNCIL DIRECTIVE 98/ 83/ EC of 3 November on the quality of water intended for human consumption, Official Journal of the European Communities, L 330/32, 1998. http://dx.doi.org/10.1017/cbo9780511610851.055

HAMED, E., SAKR, A., 2001. Application of multiple response optimization technique to extended release formulations design, J. Control. Release., 73: 329 338. http://dx.doi.org/10.1016/s0168-3659(01)00356-X

HOLT, J.G., KRIEG, N.R., SNEATH, P.H.A., STALEY, J.T., WILLIAMS, S.T., 1994. Bergey's manual of determinative bacteriology, 9th. Edn. Williams \& Wilkins, Baltimore, USA.

HONG, Q., ZHANG, Z.H., HONG, Y.F., LI, S.P., 2007. A microcosm study on bioremediation of fenitrothion-contaminated soil using Burkholderia sp FDS-1. Int Biodeter Biodeg., 59:55-61. http://dx.doi.org/10.1016/j.ibiod.2006.07.013

HORNE, I., SUTHERLAND, T.D., HARCOURT, R.L., RUSSELL, R.J., OAKESHOTT, J.G., 2002. Identification of an opd (organophosphate degradation) gene in an Agrobacterium isolate. Appl Environ Microb., 68:33713376. http://dx.doi.org/10.1128/aem.68.7.3371-3376.2002

JILANI, S, ALTAF KHAN, M., 2006. Biodegradation of cypermethrin by Pseudomonas in a batch activated sludge process. Int. J. Environ. Sci. Tech., 3(4): 371-380. http://dx.doi.org/10.1007/bf03325946
KALOYANOVA, S, TARKOWSKI, S., 1981. Toxicology of Pesticides, $1^{\text {st }}$ ed., WHO, Copenhagen.

KANEKAR, P.P., BHADBHADE, B.J., DESHPANDE, N.M., SARNAIK, S.S., 2004. Biodegradation of organophosphorus pesticides. Proct Indian natn Sci Acad B., 70 (1): 57-70.

MALGHANI, S, CHATTERJEE, N, HU, X, ZEJIAO, L., 2009. Isolation characterization of a profenofos degrading bacterium. J Environ Sci., 21:15911597. http://dx.doi.org/10.1016/s1001-0742(08)62460-2

MARTÍNEZ-TOLEDO, A., RODRÍGUEZ-VÁZQUEZ, R., 2011. Response surface methodology (Box-Behnken) to improve a liquid media formulation to produce biosurfactant and phenanthrene removal by Pseudomonas putida. Annals of microbiology, 61(3): 605-613. http://dx.doi.org/10.1007/s13213-010-0179-0

Montgomery, D.C., 1991. Design and Analysis of Experiments, 3rd ed., Wiley, New York.

Montgomery D.C., 2004. Design and analysis of experiments, 5th edition. New York: Wiley.

MYERS, R.H., MONTGOMERY, D.C., 2002. Response Surface Methodology: Process and Product Optimization Using Designed Experiments, $5^{\text {th }}$ Edition, John Wiley, New York. http://dx.doi.org/10.1080/00401706.1996.10484509

QIU, X.H., BAI, W.Q., ZHONG, Q.Z., LI ,M., HE, F.Q., LI, B.T., 2006 Isolation and characterization of a bacterial strain of the genus Ochrobactrum with methyl parathion mineralizing activity. J Appl Microbiol., 101; 986-994. http://dx.doi.org/10.1111/j.1365-2672.2006.03016.x

RAMANATHAN MP, LALITHAKUMARI D. Complete mineralization of methylparathion by Pseudomonas sp. A3. Appl Biochem Biotechnol. 2006; 80:112. http://dx.doi.org/10.1385/abab:80:1:1

SAMPAIO, G.M.M.S., 2005. Remoção de metil paration e atrazina em reatores com fungos. Tese (Doutorado em Hidráulica e Saneamento) - Escola de Engenharia de São Carlos, Universidade de São Paulo, São Carlos. http://dx.doi.org/10.1590/s0103-06631997000300006

SERDAR, C., GIBSON, D., 1985. Enzymatic hydrolysis of organophosphates: cloning and expression of a parathion hydrolase gene from Pseudomonas diminuta, Biotech., 3:567- 571. http://dx.doi.org/10.1038/nbt0685-567

SINGH, B.K, WALKER, A., 2006. Microbial degrading of organophosphorus compounds. FEMS Microbiol Rev., 30: 428- 471 http://dx.doi.org/10.1111/j.1574-6976.2006.00018.x

SUBHAS, D., DILEEP, K.S., 2003. Utilization of monocrotophos as phosphorus source by Pseudomonas aeruginosa F10B and Clavibacter michiganense subsp. insidiosum SBL11. Canadian J Microbiol., 49(2):101109. http://dx.doi.org/10.1139/w03-013

TSE H, COMBA M, ALAEE M. Methods for the determination of organophosphate insecticides in water, sediments and biota. Chemosphere.2004; 54:41-47. http://dx.doi.org/10.1016/s0045-6535(03)00659-3

USHARANI, K., LAKSHMANAPERUMALSAMY, P., MUTHUKUMAR, M., 2013. Optimization of phosphate removal from synthetic wastewater by bacterial consortium using Box-Behnken Design. Environ. Engg. Manage. J. 2013; 12(12): 2371- 2383.

WU, C., LINDEN, K.G., 2008. Degradation and byproduct formation of parathion in aqueous solutions by $\mathrm{UV}$ and $\mathrm{UV} / \mathrm{H}_{2} \mathrm{O}_{2}$ treatment. Water Res., 42 4780-4790.

YANG, O., LI, C., LI, H., LI, Y., YU, N., 2009. Degradation of synthetic reactive azo dyes and treatment of textile wastewater by a fungi consortium reactor, Biochem. Engg. J., 43: 225-230. http://dx.doi.org/10.1016/j.bej.2008.10.002

YUAN YJ, LU ZX, HUANG LJ, BIE XM, LU FX, LI Y. 2006. Optimization of a medium for enhancing nicotine biodegradation by Ochrobactrum intermedium DN2. J. Appl. Microbiol., 101: 691-697. http://dx.doi.org/10.1111/j.13652672.2006.02929.X

YUGUI T, YAOMING W, SHILEI Y, LIANBIN Y. Optimization of omethoate degradation conditions and a kinetics model, Int Biodeterior \& Biodegrad. 2008 62: 239-243.

ZHONGLI C, SHUNPENG , L, GUOPING, F. 2001. Isolation of parathiondegrading strain M6 and cloning of the methylparathion hydrolase gene. Appl
Environ
Microbiol., 67(10):
4922-4925. 